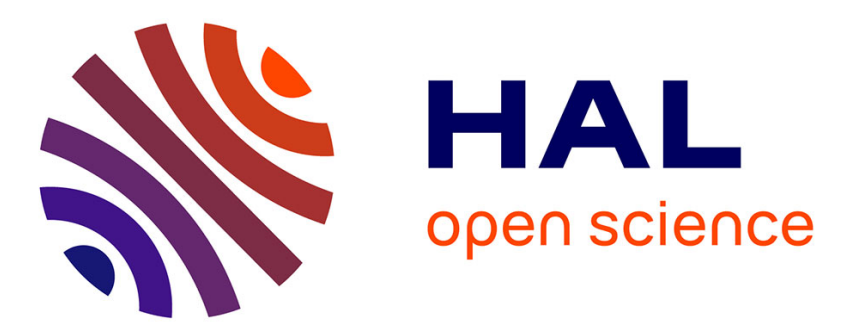

\title{
Bubble nucleation, growth and coalescence during the 1997 Vulcanian explosions of Soufrière Hills Volcano, Montserrat
}

Thomas Giachetti, Timothy H. Druitt, Alain Burgisser, Laurent Arbaret, C. Galven

\section{To cite this version:}

Thomas Giachetti, Timothy H. Druitt, Alain Burgisser, Laurent Arbaret, C. Galven. Bubble nucleation, growth and coalescence during the 1997 Vulcanian explosions of Soufrière Hills Volcano, Montserrat. Journal of Volcanology and Geothermal Research, 2010, 193 (3-4), pp.215-231. 10.1016/j.jvolgeores.2010.04.001 . insu-00488518

\section{HAL Id: insu-00488518 https://hal-insu.archives-ouvertes.fr/insu-00488518}

Submitted on 16 Nov 2010

HAL is a multi-disciplinary open access archive for the deposit and dissemination of scientific research documents, whether they are published or not. The documents may come from teaching and research institutions in France or abroad, or from public or private research centers.
L'archive ouverte pluridisciplinaire HAL, est destinée au dépôt et à la diffusion de documents scientifiques de niveau recherche, publiés ou non, émanant des établissements d'enseignement et de recherche français ou étrangers, des laboratoires publics ou privés. 


\title{
Bubble nucleation, growth and coalescence during the 1997 Vulcanian explosions of Soufrière Hills Volcano, Montserrat
}

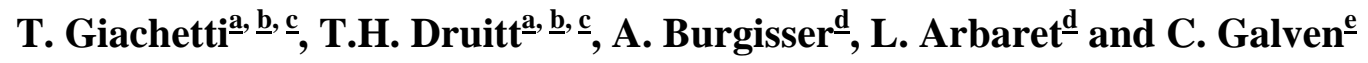 \\ ${ }^{a}$ Clermont Université, Université Blaise Pascal, Laboratoire Magmas et Volcans, BP 10448, \\ F-63000 Clermont-Ferrand, France \\ ${ }^{\mathrm{b}}$ CNRS, UMR 6524, LMV, F-63038 Clermont-Ferrand, France \\ ${ }^{\mathrm{c}}$ IRD, R 163, LMV, F-63038 Clermont-Ferrand, France \\ ${ }^{\mathrm{d}}$ Institut des Sciences de la Terre d'Orléans, Université d'Orléans, 1A, rue de la Férollerie, \\ 45071 Orléans Cedex 2, France
}

${ }^{\mathrm{e}}$ Laboratoire des Oxydes et Fluorures, Faculté des Sciences et Techniques, Université du Maine, Avenue Olivier Messiaen, 72085 Le Mans Cedex 9, France

\begin{abstract}
Soufrière Hills Volcano had two periods of repetitive Vulcanian activity in 1997. Each explosion discharged the contents of the upper $0.5-2 \mathrm{~km}$ of the conduit as pyroclastic flows and fallout: frothy pumices from a deep, gas-rich zone, lava and breadcrust bombs from a degassed lava plug, and dense pumices from a transition zone. Vesicles constitute 1-66 vol.\% of breadcrust bombs and 24-79\% of pumices, all those larger than a few tens of $\mu \mathrm{m}$ being interconnected. Small vesicles $(<$ few tens of $\mu \mathrm{m})$ in all pyroclasts are interpreted as having formed syn-explosively, as shown by their presence in breadcrust bombs formed from originally non-vesicular magma. Most large vesicles ( $>$ few hundreds of $\mu \mathrm{m}$ ) in pumices are interpreted as pre-dating explosion, implying pre-explosive conduit porosities up to $55 \%$. About a sixth of large vesicles in pumices, and all those in breadcrust bombs, are angular voids formed by syn-explosive fracturing of amphibole phenocrysts. An intermediate-sized vesicle population formed by coalescence of the small syn-explosive bubbles. Bubble nucleation took place heterogeneously on titanomagnetite, number densities of which greatly exceed those of vesicles, and growth took place mainly by decompression.
\end{abstract}

Development of pyroclast vesicle textures was controlled by the time interval between the onset of explosion-decompression and surface quench in contact with air. Lava-plug fragments entered the air quickly after fragmentation $(\sim 10 \mathrm{~s})$, so the interiors continued to vesiculate once the rinds had quenched, forming breadcrust bombs. Deeper, gas-rich magma took longer $(\sim 50 \mathrm{~s})$ to reach the surface, and vesiculation of resulting pumice clasts was essentially complete prior to surface quench. This accounts for the absence of breadcrusting on pumice clasts, and for the textural similarity between pyroclastic flow and fallout pumices, despite different thermal histories after leaving the vent. It also allowed syn-explosive coalescence to proceed further in the pumices than in the breadcrust bombs. Uniaxial boudinage of amphibole phenocrysts in pumices implies significant syn-explosive vesiculation even prior to magma fragmentation, probably in a zone of steep pressure gradient beneath the descending fragmentation front. Syn-explosive decompression rates estimated from vesicle number densities $\left(>0.3-6.5 \mathrm{MPa} \mathrm{s}^{-1}\right.$ ) are consistent with those predicted by previously published numerical models. 
Keywords: Vulcanian explosions; Soufrière Hills; vesiculation; bubble nucleation; bubble growth; coalescence; amphibole boudinage

\section{Introduction}

Explosive volcanic eruptions are driven by the nucleation, growth and coalescence of gas bubbles, followed by fragmentation of the magmatic foam into a suspension of pyroclasts and gas that is discharged at high velocities into the atmosphere. Studies of pyroclast textures, coupled with experimental and numerical approaches, have advanced understanding of these processes ([Lensky et al., 2004], [Spieler et al., 2004b], [Adams et al., 2006], [Toramaru, 2006], [Gardner, 2007], [Cluzel et al., 2008] and [Koyaguchi et al., 2008] and references therein), but many questions remain. One concerns the relative importance of homogeneous versus heterogeneous nucleation. Homogeneous nucleation requires gas supersaturations of at least several tens of MPa ([Mangan and Sisson, 2000], [Mourtada-Bonnefoi and Laporte, 2002], [Mourtada-Bonnefoi and Laporte, 2004] and [Mangan et al., 2004]), whereas heterogeneous nucleation requires lower supersaturations ([Hurwitz and Navon, 1994], [Gardner, 2007] and [Cluzel et al., 2008]). The degree of equilibrium between gas and melt during bubble growth also has an effect. Equilibrium degassing requires efficient volatile diffusion coupled with melt viscosity low enough to allow free gas expansion ([Lyakhovsky et al., 1996], [Liu and Zhang, 2000] and [Lensky et al., 2004]). High degrees of disequilibrium favour short-lived eruptions, whereas equilibrium allows more sustained fragmentation ([Melnik and Sparks, 2002] and [Mason et al., 2006]). Another issue concerns the timing of bubble growth and coalescence relative to fragmentation and eruption. Some authors postulate little growth following fragmentation (Klug and Cashman, 1991) whereas others envisage significant post-fragmentation growth ([Thomas et al., 1994] and [Kaminski and Jaupart, 1997]). Post-fragmentation bubble growth is largely controlled by melt viscosity, being important in mafic melts and less so in silicic melts with viscosities $>10^{8}-10^{9} \mathrm{~Pa} \mathrm{~s}$ ([Thomas et al., 1994], [Gardner et al., 1996] and [Kaminski and Jaupart, 1997]). Bubble coalescence and connections control permeability acquisition and the ability of magma to outgas during ascent.

Vesicle size distributions provide information on magma vesiculation history. Pumices commonly contain multiple vesicle populations covering a large range of sizes ([Klug and Cashman, 1996], [Klug et al., 2002] and [Adams et al., 2006]) that may result from coalescence following a single nucleation event ([Orsi et al., 1992], [Klug and Cashman, 1994], [Klug and Cashman, 1996], [Klug et al., 2002] and [Burgisser and Gardner, 2005]). Alternatively, each population may represent a distinct nucleation event, consistent with some ascent models which predict multiple events for viscous magma ([Whitham and Sparks, 1986], [Proussevitch and Sahagian, 1996], [Blower et al., 2001] and [Massol and Koyaguchi, 2005]). Small vesicles are commonly attributed to syn-explosive vesiculation that generates an exponential size distribution ([Mangan et al., 1993], [Klug and Cashman, 1996], [Klug et al., 2002] and [Adams et al., 2006]). Size distributions of larger populations typically obey power laws usually attributed to coalescence ([Klug et al., 2002], [Houghton et al., 2003], [Gurioli et al., 2005], [Adams et al., 2006] and [Klug and Cashman, 1996]), although multiple nucleation events also generate power-law distributions (Blower et al., 2001). Magma decompression rates can be estimated from vesicle number densities assuming a unique and brief nucleation event ([Toramaru, 2006] and [Cluzel et al., 2008]).

Detailed studies of eruptive products are required to address these questions and provide ground truth for models. Most vesiculation studies to date have concerned Plinian eruptions. 
In this paper we study vesiculation during a sequence of well documented Vulcanian explosions at Soufrière Hills Volcano in 1997. The explosions have been previously described ([Druitt et al., 2002] and [Cole et al., 2002]) and modelled ([Melnik and Sparks, 2002], [Clarke et al., 2002], [Formenti et al., 2003], [Diller et al., 2006] and [Mason et al., 2006]), and their products studied texturally ([Formenti and Druitt, 2003] and [Clarke et al., 2007]) and chemically (Harford et al., 2003). A key feature was the eruption of pyroclasts of a wide range of types, including dense lava fragments, breadcrust bombs and pumices of different densities. Textural analysis, including a set of high-resolution vesicle-size distributions, enables us to recognize populations of vesicles formed by explosion decompression, quantify bubble nucleation mechanisms and decompression rates, and constrain the timing of bubble nucleation, growth and coalescence during, and immediately following, a typical explosion. In a companion paper we present measurements of groundmass water contents and reconstruct the state of the pre-explosion conduit (Burgisser et al., in press).

\section{The 1997 Vulcanian explosions of the Soufrière Hills Volcano}

The eruption of Soufrière Hills Volcano (Fig. 1) began phreatically in July 1995; extrusion of lava began in November of the same year and continued intermittently until the time of writing. The explosions in 1997 occurred every 3-63 h (mean of $\sim 10 \mathrm{~h}$ ) in two periods: thirteen between 4 and 12 August, and seventy five between 22 September and 21 October (Druitt et al., 2002). Each consisted of an initial high-intensity phase lasting a few tens of seconds, followed by a waning phase lasting 1-3 h. Multiple jets were ejected at $40-$ $140 \mathrm{~m} \mathrm{~s}^{-1}$ during the first $10-20 \mathrm{~s}$ of each explosion, then collapsed back to form pumiceous pyroclastic flows that travelled up to $6 \mathrm{~km}$ from the crater (Formenti et al., 2003). Fallout of pumice and ash occurred from high $(3-15 \mathrm{~km})$ buoyant plumes that developed above the collapsing fountains. Fallout and flow took place at the same time from individual explosions. Each explosion discharged on average $8 \times 10^{8} \mathrm{~kg}$ of magma, about two-thirds as pyroclastic flows and one-third as fallout, representing a conduit drawdown of $0.5-2 \mathrm{~km}$ (Druitt et al., 2002). Studies of quench pressures using microlite contents and glass water contents support a maximum drawdown of $\sim 2 \mathrm{~km}$ (Clarke et al., 2007; Burgisser et al., in press). Each explosion started when magma overpressure exceeded the strength of an overlying degassed plug and a fragmentation front propagated down the conduit at a few tens of $\mathrm{m} \mathrm{s}^{-1}$ ([Druitt et al., 2002], [Clarke et al., 2002], [Melnik and Sparks, 2002], [Spieler et al., 2004a], [Diller et al., 2006] and [Mason et al., 2006]). After each explosion, magma rose up the conduit before the onset of a new explosion.

\section{Methodolgy}

Field work was carried out in 2006 and 2008 at three sites (Fig. 1): sites 1 and 2 are situated on the fans of overlapping pyroclastic flow lobes from the explosions, and site 3 is a composite layer of fallout pumice from many explosions. Fallout pumices were also collected at a fourth site (site 4; Fig. 1) during an explosion in August 1997. Field descriptions were made using a rock saw to cut perpendicular to any flow banding and parallel to any crystal fabric, and over 100 representative pyroclasts were taken for laboratory study.

Abundances of isolated and connected vesicles were measured on 2-5 cm cubes cut from 30 breadcrust bombs and 34 flow and fall pumices using a Multivolume 1305 Helium Pycnometer and the method of Formenti and Druitt (2003), which is explained in the Supplementary electronic material. 
Separate measurements were made on the rims and cores of 22 breadcrust bombs. Twenty-six of the pumice clasts ranged from lapilli to block size, all being $<20 \mathrm{~cm}$ in diameter.

Measurements were also made on multiple core-to-rim samples from eight pumices $>30 \mathrm{~cm}$ in diameter. Texturally or compositionally banded pyroclasts were not included.

Microscopic observations were made on the broken surfaces of pyroclast fragments using a Jeol JSM-591LV Scanning Electron Microscope (SEM) at an acceleration of $15 \mathrm{kV}$, and on polished epoxy-impregnated thin sections using the SEM and a stereomicroscope.

Six samples representative (in terms of vesicularity and texture) of the pyroclast assemblage were chosen for high-resolution analysis of vesicle and crystal size distributions. Banded clasts, and those with a significant fraction of non-spherical vesicles, were excluded, thereby justifying use of a single, randomly oriented thin section for each sample. Vesicle and crystal size distributions were measured by image analysis in two dimensions ([Toramaru, 1990], [Mangan et al., 1993], [Klug and Cashman, 1994], [Klug and Cashman, 1996], [Klug et al., 2002], [Adams et al., 2006] and [Shea et al., 2010]). The technique, described fully in Appendix A, allowed objects as small as $\sim 1 \mu \mathrm{m}$ to be measured. Differential epoxy penetration enabled us to distinguish interconnected from isolated vesicles. To represent the state of the magma immediately prior to the last discernible stage of coalescence, we manually 'decoalesced' neighbouring vesicles separated by a partially retracted wall. Volume distributions were assumed to equal area distributions (Klug et al., 2002). Volumetric number densities $\left(N_{v}\right)$ were calculated from area number densities $\left(N_{a}\right)$ using both the methods of Cheng and Lemlich (1983) and of Sahagian and Proussevitch (1998), which yield very similar values (Table 1). Values of $N_{v}$ presented in this paper are those obtained using the first method, for reasons discussed in the Appendix A.

\section{Field descriptions}

The pyroclast assemblage consists predominantly of pumices of different colours, vesicularities and textures, with less than a few percent of breadcrust bombs and dense glassy lava clasts. Pyroclasts of all types were present in the pyroclastic flow deposits, although the relative proportions varied from lobe to lobe, while dense lava and breadcrust bombs were absent in the fallout. The samples described below come from several different explosions, and cannot be assigned to specific dates/times owing to the complex superposition of flow and fallout lobes from the many events. They represent the products of an 'average' explosion, as justified by (1) the first-order similarity of all the explosions (Druitt et al., 2002), and (2) the presence of the entire pyroclast spectrum in all pyroclastic flow lobes we examined.

Pumices in the pyroclastic-flow deposits occur as lapilli and blocks up to $>1 \mathrm{~m}$ in diameter with subangular-to-rounded shapes due to abrasion during transport. They range from beige, well vesiculated varieties, to grey, brown or black denser varieties (Fig. 2a-b). A pink colouration affects the surfaces of many blocks, but rarely pervades the interiors. While the majority of pumices are texturally homogeneous in hand specimen, some denser ones are flow banded with phenocryst alignment in the plane of banding. Rare compositional banding defined by trails of disintegrated mafic inclusions also occurs. All pumice clasts (as distinguished from breadcrust bombs) lack surface breadcrusting. This probably cannot be explained by abrasion, because breadcrust fragments are not observed in the flow matrices. All pumices smaller than $\sim 30 \mathrm{~cm}$ lack radial gradients in vesicle abundance or size. However, some blocks larger than this exhibit visibly obvious radial gradients in vesicle size, with an outer 3-7-cm-thick rind with vesicles up to several $\mathrm{mm}$, and a more coarsely vesicular interior 
containing vesicles up to an order of magnitude larger (Fig. 2c). In some cases a crude cmscale radial jointing affects the rind. The rind is inferred to represent the initial textural state of the pumice, while the interior records vesicle coarsening that took place during or after emplacement. The possibility that the interior represents the initial state, and that the rind developed by compaction during rolling in the pyroclastic flow, is not favoured because (1) the rinds texturally resemble the majority of smaller pumice blocks and lapilli, whereas vesicles in the interiors are abnormally coarse, and (2) no circumferential flattening of rind vesicles is observed. Many blocks also contain large voids up to several $\mathrm{cm}$ across, including anastamosing vesicle pipes and channels, ductile tears in the plane of flow banding, and curviplanar tears and cracks subparallel to clast margins (Fig. 2d), which together account for $<10 \%$ of the total vesicularity.

Fallout pumices are up to several $\mathrm{cm}$ in size and most preserve their original eruptionfragmentation shapes, unmodified by abrasion in pyroclastic flows or breakage on ground impact. They range in colour from white to brown and in shape from spheroidal to tabular, the latter comprising about three-quarters of the sample suite. Again, no surface breadcrusting is observed.

Breadcrust bombs occur from a few $\mathrm{cm}$ to over a metre in diameter. They have vesicular interiors surrounded by darker, less vesicular $<10 \mathrm{~mm}$ glassy rinds. A continuous range of textural varieties are observed between two endmembers. Coarsely breadcrusted bombs are relatively dense, with well defined, dark-grey-to-black, poorly-to-non-vesicular rinds, broad, deep surface fractures defining large polygons, and grey-to-brown vesicular interiors (Fig. 2ef). Finely breadcrusted bombs are less dense, with diffuse, pale vesicular rinds, finer polygonal networks of narrower, shallower surface fractures, and paler, commonly flowbanded interiors (Fig. 2g-h). Some bombs that broke during eruption exhibit two generations of breadcrusting, the breakage surface being more finely breadcrusted than the original, outer surface of the bomb. Breakage is inferred to have exposed the already vesicular interior, which then developed a second generation of finer breadcrusting. Bombs were abraded during transport in the pyroclastic flows; most lack completely preserved breadcrust surfaces with sharp edges and corners, and partial rind removal, rounding of polygon edges, and abrasion of vesicular interiors are common.

Clasts of black, essentially nonvesicular lava resembling the glassy rinds of the coarsely breadcrust bombs are interpreted as an integral component of the explosion-pyroclast suite. On the other hand, grey-to-brown holocrystalline lava and cinderblock clasts resembling typical dome rock are probably derived either from the crater walls or from earlier block-andash flow deposits traversed by the explosion pyroclastic flows.

\section{Pyroclast vesicularities}

Vesicularities of texturally homogenous pumice lapilli and blocks range from 24 to 79 vol.\% (Fig. 3) and correlate with colour, being lowest in darker pumices and higher in paler ones. The fraction of isolated vesicles (isolated divided by total vesicularity) is universally low $(<0.25$, with $85 \%<0.1)$. Flow pumices cover the entire vesicularity range and have isolated fractions of $0-0.13$, whereas fallout pumices have vesicularities of $43-72$ vol. $\%$ and isolated fractions of $0.04-0.14$, a single sample having 0.25 (Fig. 3). No variation of either vesicularity or isolated vesicle fraction with clast size is observed. 
Vesicularity profiles across eight $>30 \mathrm{~cm}$ pumice blocks are shown in Fig. 4. Four of these appeared homogeneous in the field, and four had visually obvious radial gradients in vesicle size. The four homogeneous blocks (SHV4-12-13-22) lack significant gradients in vesicularity from core to rim, as anticipated from inspection. The four vesicle-size-graded blocks (SHV2-14-23-25), on the other hand, exhibit vesicularity gradients, but these vary from sample to sample and no systematic decrease in vesicularity from core to rim is evident. The coarse interiors of these pumices are no more vesicular than the more finely vesicular rims. Textural coarsening in the interiors therefore took place without inflation, as consistent with the absence of surface breadcrusting.

Breadcrust-bombs differ from pumices in that (1) their vesicularity range (20-66 vol.\% most lying between 35 and 55\%, Fig. 3) is smaller, and highly vesicular (>66\%) samples are not observed; and (2) the fraction of isolated pores $(0.05-0.33,>80 \%$ being $0.1-0.2)$ is higher than in pumices of similar vesicularity. Bomb rinds contain $1-25$ vol. $\%$ vesicles, most of which are isolated. Rind and interior vesicularities are broadly correlated (Fig. 5). Coarsely breadcrusted bombs have the lowest vesicularities, both in rinds and interiors, and finely breadcrusted bombs are more vesicular. It is the existence of vesicular rinds on finely breadcrusted bombs that gives these bombs their pale colours and make distinction between rind and interior less clear than in the coarsely breadcrusted bombs.

\section{Microscopic vesicle textures}

The pyroclasts contain vesicles with a broad range of sizes set in microlite-bearing groundmass. In this section we focus on vesicles less than a few $\mathrm{mm}$ in diameter present in hand specimens, and distinguish three populations: small (less than a few tens of $\mu \mathrm{m}$ ), intermediate (few tens to a few hundreds of $\mu \mathrm{m}$ ) and large (few hundreds of $\mu \mathrm{m}$ to a few $\mathrm{mm}$ ). It is shown later that these three populations also have genetic significance.

Vesicle textures in fallout and flow pumices are very similar and are described together. The large vesicles form interconnected networks with curved, scalloped walls indicative of coalescence. Large vesicles in the more vesicular pumices are quasi-spherical to elliptical in shape. Those in dense pumices commonly have more ragged, fissure-like shapes, suggesting that perhaps they already existed prior to explosion. About $15 \%$ of the large vesicles are angular voids associated with fractured amphibole phenocrysts (Fig. 6a). Intermediate-sized vesicles in all pumices have variably rounded to ragged shapes and, like the large ones, form interconnected networks in three dimensions. In contrast, small vesicles are commonly spherical and many are isolated; they either form a 'matrix' in which the intermediate vesicles are dispersed (Fig. 6b), or are situated in the walls separating the latter. In some samples the smallest isolated vesicles form sub-spherical clusters several tens of microns in diameter that protrude with bulbous, cauliform shapes into larger vesicles (Fig. 6c; Formenti and Druitt, 2003). There is textural evidence that many vesicles of intermediate size formed by coalescence of the small vesicles (rather than pre-existing them), the process commonly being preserved quenched in progress (Fig. 6d). The sizes of some intermediate vesicles appear to be inherited from the clusters of small vesicles when the latter coalesced while preserving the overall sub-spherical form of the cluster.

Vesicles in pumices are commonly observed in spatial association with phenocrysts. Large, angular voids are associated with fractured amphiboles, and have two endmember types: (1) voids in amphiboles boudinaged uniaxially in the plane of flow foliation, with well defined 
length-perpendicular fractures (Fig. 7); (2) voids in amphiboles that are fractured both perpendicular and parallel to length, and the fragments dispersed around the vesicle margins in a manner suggestive of more isotropic expansion. In both types, crystal fragments are commonly connected by thin, delicate threads of glass generated either by the bursting of melt inclusions, or by the pulling-out of thin, pre-existing melt films in incipient cracks. A single type of amphibole-associated void is commonly dominant within a given pumice block. Type

1 is observed in $45 \%$ of pumices and type 2 in $~ 35 \%$, the remaining $\quad 20 \%$ of pumices lacking voids associated with amphibole. Another common texture involves radial arrangements of stretched vesicles around phenocrysts of plagioclase or amphibole (Fig. 6e). This is attributed to expansion of a magmatic foam around a rigid crystal; it cannot be due to heterogeneous bubble nucleation because in each case the vesicles are separated from the crystal by a thin glass film, showing that the crystal was not wetted by gas. Only in the case of titanomagnetite is it common to see vesicles in direct contact with crystals without intervening glass, suggesting that titanomagnetite provided nucleation sites for bubbles (Fig. 8).

There is abundant evidence that bubble coalescence was ongoing at all scales larger than a few $\mu \mathrm{m}$ at the time of sample quench: ovoid, neck-like connections with partially retracted walls between neighbouring vesicles (Fig. 6d), wrinkling of thin vesicle walls (Fig. 6f), the occurrence of thin glass fibres, and the interconnection of all but a fraction of the smallest vesicles. Minimum observed vesicle wall thicknesses are $<1 \mu \mathrm{m}$.

Breadcrust bomb rinds contain small, mostly isolated, vesicles that are irregularly distributed, being most abundant near rind-penetrating surface fractures and around phenocrysts (Fig. 9a, c). Areas of vesicle-free groundmass occur in the rinds of coarsely breadcrusted bombs, but not in those of the finely breadcrusted bombs. The lower limit of the rind is commonly marked by string-like networks of small vesicles, which then merge to form the more uniformly distributed vesicle population of the interior. The interiors of all bombs contain distinct large and small vesicle populations. Large vesicles are invariably associated with fractured amphiboles, like those in the pumices. However, well developed uniaxial boudinage is never observed in breadcrust bombs, and the voids are mostly of the more isotropic type 2 . Small vesicles are uniformly distributed throughout the bomb interiors (Fig. 9b, d); they are mostly isolated, with quasi-spherical forms, and commonly occur in strings and clusters around crystals and large vesicles. Evidence for vesicle coalescence is abundant in bomb interiors, although less so than in pumices.

\section{Size distributions of vesicles and crystals}

The six samples chosen for analysis of vesicle and crystal size distributions were a coarsely breadcrusted bomb (BCP1), a finely breadcrusted bomb (BCP43), three pyroclastic-flow pumices (AMO29, AMO36 and PV3), and a fallout pumice (R2). Separate measurements were made on the rinds and interiors of the two breadcrust bombs. Groundmass water contents of five of the samples were analysed by Burgisser et al. (in press). The data are listed in Table 1.

Glass-referenced vesicle-volume distributions are shown in Fig. 10, with connected and isolated vesicles distinguished. The limits between different image magnifications are also shown. No major artefacts related to changes in magnification are apparent; some small discontinuities in the distributions of AMO29 and PV3 may be artefacts, but no conclusions 
are based on these. Total vesicularities calculated by image analysis are within 4 vol.\% of pycnometry measurements on the same clasts (Table 1).

Vesicle-volume distributions of the breadcrust bombs are markedly bimodal. The large population is accounted for entirely by amphibole-associated voids. The small vesicles form a narrow, well defined peak; those in the rinds are entirely isolated and form a mode at $<10 \mu \mathrm{m}$, whereas in the bomb interiors a significant fraction are interconnected and the size mode is larger $(\sim 20 \mu \mathrm{m})$. The interior of the finely breadcrusted bomb contains a minor population of intermediate-sized vesicles. The distributions of all four pumices are also roughly bimodal, with a size gap at $\sim 200-500 \mu \mathrm{m}$. The finer mode is, however, much broader than in the breadcrust bombs, consisting of comparable proportions of small and intermediate-sized vesicles. The small population resembles that in the breadcrust bombs and contains all the isolated vesicles present. The intermediate population forms a coarse-tail shoulder on the small population. In pumices PV3 and R2, the small and intermediate populations form distinct sub-peaks at 10-20 and 65-80 $\mu \mathrm{m}$, respectively.

The proportions of the three populations were estimated from Gaussian best fits using the KWare SFT software. There is no physical basis for this; it is simply better than eyeballing. Grouping all samples, the modes of the three populations are 10-24 $\mu \mathrm{m}$ (small), 40-142 $\mu \mathrm{m}$ (intermediate) and 455-2299 $\mu \mathrm{m}$ (large) (Table 1). The small population constitutes 15-37\% of the vesicularity of the breadcrust bomb rinds, $62-71 \%$ of that of the breadcrust bomb interiors and $38-53 \%$ of that of the pumices. The intermediate and large populations account for $25-44 \%$ and $12-37 \%$ of pumice vesicularity, respectively.

Vesicle size distributions can also be plotted using vesicle population number density, which is equal to the slope of the cumulative number distribution (Fig. 11). Number distributions are dominated by the smallest vesicles; in our samples more than $99 \%$ of the vesicularity in number terms consists of vesicles of the small population. The distributions are curved for all samples and at all size scales, emphasizing the importance of coalescence of vesicles larger than a few $\mu \mathrm{m}$. If number distributions are redrawn cumulatively (Fig. 12), then all samples define approximately linear trends at $>30 \mu \mathrm{m}$. Linear trends on such plots depict power-law distributions, the slope being a fractal dimension ([Gaonac'h et al., 1996a], [Gaonac'h et al., 1996b] and [Blower et al., 2001]). The data give slopes ranging from -1.9 to -3.4 , being lowest in pumices $(-2.9$ to -3.4$)$, intermediate in breadcrust-bomb interiors $(-2.7$ to -2.8$)$ and highest in breadcrust-bomb rinds ( -1.9 to -2.3 ; Table 1$)$. Vesicles smaller than $30 \mu \mathrm{m}$ fall off the power-law trends, defining a different tendency. Total vesicle number densities range from 10 to $67 \times 10^{14} \mathrm{~m}^{-3}$ (method of Cheng and Lemlich 1993). Values for isolated vesicles alone range from 10 to $29 \times 10^{14} \mathrm{~m}^{-3}$. No systematic correlation with pyroclast vesicularity is observed.

A vesicle circularity index $C=4 \pi A / P^{2}$ ( $A$ is surface area and $P$ is perimeter) is plotted on Fig. 10 as a function of vesicle size, with separate curves for isolated and connected vesicles. A spherical vesicle would have a $C \approx 1$, whereas a chain of newly coalesced vesicles would approach $C \approx 0$. Isolated vesicles are systematically more circular than connected ones of similar size. Despite some artefacts related to image magnification limits (e.g., $\sim 40$ and $\sim 250 \mu \mathrm{m}$ in AMO29), $C$ values of connected vesicles in general decrease with increasing vesicle size throughout the intermediate and large populations, consistent with their more ragged shapes inherited from coalescence, the number of coalescence events increasing with vesicle size. 
Crystal volume distributions for the six pyroclasts (Fig. 13) are presented for comparison with the vesicle distributions. Two main populations can be recognised: phenocrysts larger than a few hundred $\mu \mathrm{m}$, and microphenocrysts and microlites of 300 to $1 \mu \mathrm{m}$, a bimodality being present in three samples (AMO29, AMO36 and R2). Total crystal contents, calculated vesicle-free, are lowest (55 vol.\%) in the most vesicular pumice (PV3), intermediate in denser pumices (66-73 vol.\%; AMO29, AMO36 and R2), and highest in the breadcrust bombs (5479 vol.\%) (Table 1). This is due primarily to a greater abundance of microphenocrysts and microlites in the denser pyroclasts (Fig. 13), as observed by other authors ([Murphy et al., 1998] and [Clarke et al., 2007]). Total glass-referenced crystal number densities range from 131 to $357 \times 10^{14} \mathrm{~m}^{-3}$, values for Fe-Ti oxides (mainly titanomagnetite) alone being 77 to $174 \times 10^{14} \mathrm{~m}^{-3}$. No systematic variations of crystal number density with pyroclast type, or between rinds and cores of breadcrust bombs, are observed. There is no correlation between crystal and vesicle number densities.

\section{Discussion}

\subsection{Pre-explosion conduit stratigraphy}

Previous studies enable us to reconstruct conduit stratigraphy immediately prior to an average 1997 explosion. Approximate conduit pressures for the explosion pyroclasts have been estimated using two independent methods, microlite abundance and groundmass-glass water content, both of which yield similar results (Clarke et al., 2007; Burgisser et al, in press). Glassy lava, breadcrust bombs and poorly vesicular $\left(<40\right.$ vol.\%) pumices yield $P_{\mathrm{H} 2 \mathrm{O}}$ values of $0-10 \mathrm{MPa}$, whereas more vesicular pumices ( $>40 \mathrm{vol} . \%$ ) yield up to $55 \mathrm{MPa}$. The data are consistent with the existence of a dominant, gas-rich zone (highly vesicular pumices) that passed upwards into a thin, largely degassed plug (lava fragments and breadcrust bombs) through a partly degassed region (dense pumices) (Clarke et al., 2007; Burgisser et al. in press). This interpretation ignores any possible horizontal variations in the conduit (Kennedy et al., 2005). Variations in pyroclast proportions between different pyroclastic flow lobes are attributed to withdrawal from different levels in the conduit, lobes richer in dense pumice being derived from higher levels of the conduit and those richer in more vesicular pumice coming from deeper.

Crystals (phenocrysts, micro-phenocrysts and microlites) in the pyroclasts are interpreted as having grown prior to explosion, either at depth or during slow viscous ascent between explosions (Clarke et al., 2007). This is supported by the lack of correlation between the number densities of crystals and vesicles in our samples, as well as by the presence of high crystal number densities in the (rapidly quenched) rinds of coarsely breadcrusted bombs (Table 1).

\subsection{Origins of the vesicle populations}

A vesicle is here termed 'syn-explosive' if it nucleated during and/or immediately following the explosion that ejected its host pyroclast. It is 'pre-explosive' if it already existed prior to the explosion in question, having nucleated either during previous explosions and/or during the 3-63 hours of slow viscous ascent between explosions.

Vesicles of the small population (less than a few tens of $\mu \mathrm{m}$ ) are present in all pyroclasts, and are interpreted as having nucleated and grown syn-explosively. The principal argument is that they dominate the interiors of coarsely breadcrusted bombs, in which a syn-explosive origin is 
unambiguous. Coarsely breadcrusted bombs inflated syn-explosively from essentially nonvesicular initial states, as shown by the common presence in the rinds of large areas of vesicle-free groundmass (e.g., [Walker, 1982] and [Wright et al., 2007]). All vesicles in the bomb interiors must therefore be syn-explosive and post-date fragmentation. The small size, high sphericity and high isolated fraction of these vesicles is consistent with nucleation and rapid growth shortly before quenching (e.g. [Mourtada-Bonnefoi and Laporte, 2002], [Mangan et al., 2004] and [Gardner and Denis, 2004]). The similarity between small vesicles in the pumices and finely breadcrusted bombs with those in the coarsely breadcrusted bombs leads us to interpret all vesicles of this population as syn-explosive.

Vesicles of the intermediate population occur in all pumices as a coarse tail to the small population; they are also present in minor quantities in the interiors of finely breadcrusted bombs, but are absent from coarsely breadcrusted bombs. Since many are observed to have formed by coalescence of the small-population vesicles, they too must be largely synexplosive in origin. Some appear to have inherited their sizes from internally coalesced vesicle clusters, perhaps explaining the distinct small and intermediate size peaks in some pumices (Fig. 10).

Large-population vesicles are interpreted as having a mixed origin. Those in the breadcrust bombs are invariably amphibole-associated voids that must be syn-explosive because (1) they are present in the interiors of coarsely breadcrusted bombs, but not in the rinds, (2) they are commonly traversed by delicate glass filaments indicative of a very late-stage origin. The $\sim 15 \%$ of large vesicles associated with boudinaged amphiboles in pumices are also inferred to be syn-explosive, for the same reasons. The remaining $\sim 85 \%$ of large vesicles in pumices are not associated with phenocrysts, and may be pre-explosive in origin, although possibly enlarged by syn-explosive decompression. The pre-explosive origin of these large vesicles is supported by the abundance in some dense pumices of fissure-like networks of large vesicles that appear to be too well developed to have formed during explosion, and which are tentatively interpreted as having acted as outgassing pathways prior to explosion.

Some cm-sized ductile tears and cracks parallel to flow banding or clast margins commonly observed in large pumice blocks are envisaged to have formed (syn-explosively) upon ballistic impact or during transport in pyroclastic flows.

Ignoring second-order modes, the vesicle-size distributions of all pumices and breadcrustbomb interiors are essentially bimodal (Fig. 10), with a gap from a hundred to a few hundred $\mu \mathrm{m}$. Vesicle bimodality is observed commonly in pyroclasts from explosive eruptions ([Whitham and Sparks, 1986] and [Klug et al., 2002]). In the breadcrust bombs of the present study, bimodality is explained by syn-explosive vesiculation at two scales: (1) nucleation and growth of small bubbles and (2) formation of large voids, the sizes of which are imposed by those of amphibole phenocrysts. Bimodality in the pumices is tentatively explained by combining (1) vesicles formed by syn-explosive nucleation, growth and coalescence (small and intermediate populations) with (2) a large population composed of syn-explosive, phenocryst-related voids and pre-explosive bubbles.

Interestingly, the size gaps in the pumice vesicle-size distributions correspond approximately with gaps in corresponding crystal size distributions. Crystals in all four pumices have size gaps between microlite/microphenocryst and phenocryst populations that coincide approximately with those of vesicles. This is a real feature, not a measurement artefact. Since the short explosion timescale does not permit significant syn-explosive crystal growth, any 
interrelationship must involve length-scale imposition on growing bubbles by crystals that were already present. Crystals, being rigid objects, will influence the sizes, shapes and distributions of nearby bubbles (e.g., Fig. 6e). Voids created by crystal fracture will have length scales imposed on them by the crystal (e.g., Fig. 6a).

\subsection{Amounts of pre-explosive and syn-explosive vesiculation}

Syn-explosive vesicularity includes the small and intermediate populations, all the large population in breadcrust bombs, and at least $\sim 15 \%$ of the large population in pumices. The breadcrust bombs inflated from essentially non-vesicular magma, whereas the pumices had pre-explosive porosities corresponding to no more than $\sim 85 \%$ of the large population, quantified as follows. Define the following component fractions: $X_{\mathrm{lv}}$ (large vesicles), $X_{\mathrm{siv}}$ (small + intermediate vesicles), $X_{\mathrm{xt}}$ (crystals) and $X_{\mathrm{gl}}$ (glass). Pre-explosive pumice vesicularity is given by $100 \times 0.85 X_{\mathrm{lv}} /\left(0.85 X_{\mathrm{lv}}+X_{\mathrm{xt}}+X_{\mathrm{gl}}\right)$. This yields $11-47 \mathrm{vol} . \%$ for the pumices in Table 1, and is greatest for the most vesicular one (47\%; PV3). These are maximum estimates, because the pre-explosive bubbles could have expanded during explosion decompression.

An independent estimate is provided by uniaxially boudinaged (type 1) amphibole phenocrysts in pumice, which are interpreted as providing a measure of strain during synexplosive expansion (Fig. 7). Although the strain recorded by some isotropically fractured (type 2) amphiboles could be partly due to gas release from vesiculated melt inclusions, we consider it unlikely that this is the case for the uniaxial case. The apparent strain varies widely between pyroclasts, probably due to different amounts of syn-explosive vesiculation as well as variable degrees of slip between melt and solid at the crystal surface, but the largest values (void length divided by crystal length) are about $2 / 3$. Now defining $X_{\text {pre }}$ as the fraction of preexplosion vesicles, then $X_{\mathrm{lv}}+X_{\text {siv }}-X_{\text {pre }}$ is the fraction of syn-explosive vesicles and we have $\left(X_{\mathrm{lv}}+X_{\text {siv }}-X_{\text {pre }}\right) /\left(X_{\text {pre }}+X_{\mathrm{xt}}+X_{\mathrm{gl}}\right) \approx 2 / 3$. Solving this for $X_{\text {pre }}$ and converting to vesicularity yields maximum pre-explosive porosities of $27-57 \%$, which are similar to the previous estimates and again greatest for the most vesicular pumice (57\%). Amphibole boudinage is therefore consistent with the small and intermediate vesicle populations in pumices being synexplosive in origin. We conclude that pre-exposive porosity in the deep, gas-rich zone of the conduit was $<55 \%$.

\subsection{Timing of syn-explosive vesiculation}

Breadcrust bombs and pumices preserve evidence for different vesiculation histories. Bubble nucleation and growth in the pumices was essentially confined to the conduit, based on the following evidence. First, the absence of vesicularity gradients and breadcrusting in pumices shows that inflation was complete before surface quench in contact with the air. Second, flow and fall pumices have similar vesicle textures, contents and size distributions, despite different thermal histories once exited the vent. Third, the existence, in $\sim 45 \%$ of the pumices, of amphiboles boudinaged uniaxially in the plane of flow foliation shows that vesiculation of at least this percentage of pumices was well advanced prior to fragmentation in order for the boudinage to be uniaxial. More complex modes of amphibole breakage, both perpendicular and parallel to crystal length, may be due to increasingly isotropic decompression and inflation as fragmentation generated progressively smaller, more equant magma parcels. Synexplosive vesiculation in pumices commenced prior to fragmentation, and in many cases continued after fragmentation, but was complete prior to the onset of clast surface cooling. The peak phase of each explosion typically lasted a few tens of seconds (Druitt et al. 2002). 
Once in the air, clast surfaces cooled quickly (another 10-20 s), causing rapid disappearance of incandescence on night video footage. Vesiculation was therefore complete in less than a minute after explosion onset, even for the deepest-derived magma. Only late-stage impactgenerated tearing and fracturing of pumices generated further voidage.

Being derived from the top of the conduit, initially non-vesicular magma of the coarsely breadcrusted bombs was fragmented and entered the air almost immediately after explosion onset. Immediate cooling quenched the bomb surface, while the hot core inflated. Nearuniversal abrasion of rinds and interiors shows that bomb inflation was complete well before the pyroclastic flows ceased movement $\sim 300 \mathrm{~s}$ later. Detailed work on breadcrust bombs at Pinchincha Volcano also documented rapid bomb inflation (Wright et al. 2007). The histories of finely breadcrusted bombs are inferred to have been intermediate between those of pumices and coarsely breadcrusted bombs. Being derived from slightly deeper in the conduit, there was some time for initial bubble nucleation and growth throughout the clast before the surface was quenched and further inflation was limited to the interior.

Syn-explosive vesiculation was thus controlled by the time available between decompression onset and quench (Fig. 14). This was shortest for the breadcrust bomb rinds, intermediate for the bomb interiors, and longest for the pumices. Neo-formed vesicles preserved in the rapidly quenched rinds of breadcrust bombs are small and isolated. During inflation of the more slowly cooled interiors, these vesicles grew (shifting the mode of the isolated ones) and began to coalesce. Syn-explosive coalescence is most advanced in the pumices because the time available between decompression onset and quench was longest.

\subsection{Mechanisms of syn-explosive vesiculation}

\subsubsection{Bubble nucleation}

Homogeneous nucleation in water-rich rhyolitic melts requires supersaturation pressures of 60-310 MPa ([Mourtada-Bonnefoi and Laporte, 1999], [Mourtada-Bonnefoi and Laporte, 2002] and [Mangan and Sisson, 2000]), which exceed the decompressions of a few to $\sim 55 \mathrm{MPa}$ experienced by the 1997 pyroclasts (Burgisser et al., in press). This implies that syn-explosive nucleation took place heterogeneously. Of the crystalline phases present in Soufrière Hills magma, only titanomagnetite has been shown to provide effective sites for bubble nucleation at supersaturations as low as a few MPa ([Hurwitz and Navon, 1994], Gardner et al., 1999 J.E. Gardner, M. Hilton and M.E.R. Carroll, Experimental constraints on degassing of magma: isothermal bubble growth during continuous decompression from high pressure, Earth Planet. Sci. Lett. 168 (1999), pp. 201-218. [Gardner et al., 1999], [Gardner et al., 2000], [Gardner and Denis, 2004], [Gardner, 2007] and [Cluzel et al., 2008]). Moreover, Fe-Ti oxides (mostly titanomagnetite) are present in the explosion pyroclasts with number densities 1.4 to 9 times higher than those of vesicles, showing that sufficient nucleation sites were available (Table 1). Textures observed on SEM images are consistent with bubble nucleation on titanomagnetite (Fig. 8).

The number densities of small and intermediate vesicles (Table 1) permit estimation of synexplosive decompression rates ([Toramaru, 2006] and [Cluzel et al., 2008]). Nucleation generates a stationary bubble number density $N_{\text {stat }}$ that is independent of saturation pressure, but dependent on the mean decompression rate $\mathrm{d} P / \mathrm{d} t$ : 


$$
\left|\frac{d P}{d t}\right| \approx a D \sigma^{2}\left(\frac{N_{\text {stat }}^{4}}{P_{\text {sat }}^{2} T^{3}}\right)^{1 / \sigma}
$$

where $D$ is water diffusivity, $\sigma$ is interfacial surface tension between melt and vapour, $P_{\text {sat }}$ is initial saturation pressure, $T$ is absolute temperature, and a is a constant $\left(3.5 \times 10^{14}\right.$ in SI units). For heterogeneous nucleation, $\sigma$ is replaced by an effective value in the presence of the crystalline phase. Heterogeneous bubble number densities $N_{v}$ theoretically vary both with the number of available nucleation sites and decompression rate, with two cases (Cluzel et al., 2008): (1) the density of available nucleation sites $N_{n}$ is greater than $N_{\text {stat }}$, in which case $N_{v} \approx N_{\text {stat }}$ and $N_{v}$ depends only on $\mathrm{d} P / \mathrm{d} t$ through Eq. (1); (2) $N_{n}<N_{\text {stat }}$, in which case $N_{v} \approx N_{n}$ $\left(<N_{\text {stat }}\right)$, and the equation cannot be used. Since oxide number densities in our samples are much higher than vesicle number densities (case 1), we can use $N_{v}$ to estimate $\mathrm{d} P / \mathrm{d} t$. This assumes that sufficient time was available for bubble number densities to reach stationary values prior to quench; if not, $\mathrm{d} P / \mathrm{d} t$ is under-estimated.

We calculate syn-explosive $\mathrm{d} P / \mathrm{d} t$ values for a typical breadcrust bomb interior, a dense pumice and a highly vesicular pumice using our data for $N_{v}$ (Table 1), the interstitial glass water contents and $P_{\text {sat }}$ estimations of Burgisser et al. (in press), and $\sigma \sim 0.025 \mathrm{~N} \mathrm{~m}^{-1}$ appropriate for nucleation on titanomagnetite (Cluzel et al., 2008). The values range from 0.3 to $6.5 \mathrm{MPa} \mathrm{s}^{-1}$. No correlation with pyroclast type is observed, perhaps due to errors associated with estimates of water content (through $D$ ), $N_{v}$ and $P_{\text {sat }}$ for the different samples.

\subsubsection{Bubble growth}

Bubble growth is driven by decompression and volatile diffusion, and resisted by melt viscosity ([Sparks, 1978], [Thomas et al., 1994], [Gardner et al., 1996], [Proussevitch and Sahagian, 1996] and [Gardner et al., 2000]). Growth during decompression from an initial pressure $P_{i}$ is governed by three characteristic timescales (Lensky et al., 2004): a decompression time $\tau_{d e c}=P_{\text {sat }} /(\mathrm{d} P / \mathrm{d} t)$, a diffusive time $\tau_{\text {diff }}=R_{i}^{2} / D_{i}$ and a viscous relaxation time $\tau_{v i s c}=4 \eta_{i} / P_{\text {sat }}$, where $R_{i}, D_{i}$ and $\eta_{i}$ are bubble radius, diffusion coefficient, and melt viscosity at the initial stages of growth. If $\tau_{v i s c} \geq \tau_{d e c}$, then viscosity is high enough to significantly inhibit bubble growth, whereas if $\tau_{v i s c} \leqslant \tau_{d e c}$, then bubbles can expand freely to ambient pressure. The latter regime can in turn be subdivided. If diffusion is fast relative to decompression, $\tau_{\text {diff }} \leqslant \tau_{\text {dec }}$, then degassing takes place at equilibrium and bubbles grow by both diffusion and decompression-driven expansion, whereas if the converse is true, diffusive transfer is negligible and bubbles grow by decompression-driven expansion alone.

The three timescales are estimated for the explosion pyroclasts in Table 2 . We also included a typical breadcrust bomb rind at a temperature close to that of the glass transition $\left(\sim 700{ }^{\circ} \mathrm{C}\right.$ in silicic melts with 1-3 wt.\%; Dingwell, 1998). As discussed above, decompression of a breadcrust bomb from the top of the conduit took place over $10 \mathrm{~s}$, whereas pumices from deeper in the conduit took a few tens of $\mathrm{s}$. Consider the case of a 10- $\mu \mathrm{m}$-diameter synexplosive bubble. For the pumices we find that $\tau_{\text {dec }} \geq \tau_{\text {diff }} \gg \tau_{\text {visc }}$, implying that melt viscosity was sufficiently low for bubbles to expand freely to near-ambient pressure. Diffusion was able to occur on the timescale of decompression, but was insufficiently fast to attain equilibrium, in agreement with high remnant water contents in interstitial glasses. For the breadcrust bomb interior $\tau_{d e c} \geq \tau_{\text {diff }}>\tau_{\text {visc }}$, implying again disequilibrium outgassing, but also that viscosity was high enough at these lower water contents to now partially limit bubble 
growth. Finally, cooling of the breadcrust bomb rind has the combined effect of significantly raising melt viscosity and slowing diffusion, such that $\tau_{v i s c} \gg \tau_{d i f f}>\tau_{d e c}$ and any bubbles that nucleated were unable to grow on the timescale available (i.e., they were viscosity-quenched; Thomas et al., 1994), again in agreement with observations.

\subsubsection{Bubble coalescence}

Textural evidence for coalescence is found in all vesicle size classes; only the small population contains isolated vesicles. Bubble-wall thinning and rupture in an expanding foam is driven by bubble growth and pressure gradients (Navon and Lyakhovsky, 1998). Abundant $<1 \mu \mathrm{m}$ bubble walls, sometimes with wavy, unstable forms, are consistent with rupture at about this thickness (Klug and Cashman, 1996). Number-size distributions for vesicles larger than a few tens of microns have power-law shapes with fractal dimensions of -1.9 to -3.4 attributed to coalescence ([Gaonac'h et al., 1996a], [Gaonac'h et al., 1996b] and [Klug et al., 2002]). Pumice fractal dimensions are similar to those at Mount Mazama ( -3.0 to -3.5 ; Klug et al., 2002), and slightly higher than those at Novarupta (- 3.9; Adams et al., 2006). The degree of coalescence increases from breadcrust-bomb rinds, to breadcrust-bomb interiors, to pumices, as witnessed by progressively lower fractal dimensions $(-1.9$ to $-2.3,-2.7$ to -2.8 and -2.9 to -3.4 , respectively) and higher proportions of intermediate-sized vesicles $(0,0$ to 9 , and 25 to $44 \%$, respectively). This is attributed to the progressively longer time interval between decompression (and bubble nucleation) and quench. Moreover, the fraction of isolated vesicles is in general lower in pumices than in breadcrust bombs, based on either pycnometry or image-analysis data (Table 1). Advanced coalescence on timescales of a few to a few tens of seconds is consistent with laboratory experiments on vesiculating rhyolitic melts ([Westrich and Eichelberger, 1994], [Navon and Lyakhovsky, 1998], [Larsen et al., 2004] and [Burgisser and Gardner, 2005]).

Coalescence continued in the hot interiors of $>30 \mathrm{~cm}$ pumices for some time after explosion, forming bubbles up to a $\mathrm{cm}$ or more in some metre-sized clasts. The lack of systematic radial vesicularity gradients and surface breadcrusting show that this must have taken place without expansion. Coalescence in a static foam is driven by capillary forces and gravitational drainage of melt films (Navon and Lyakhovsky, 1998). It must have taken place on a timescale shorter than that required for the cores of large pumices to cool from magmatic temperature $\left(\sim 850^{\circ} \mathrm{C}\right)$ through the glass transition $\left(\sim 700^{\circ} \mathrm{C}\right.$; Dingwell, 1998). The time for the core temperature of a sphere of diameter $d$ to cool conductively by $20 \%$ in contact with air is $0.08 d^{2} / 4 k$, where $k$ is thermal diffusivity (Carslaw and Jaeger, 1959, section 9.3.IV).

Thermal diffusivity of pumice is a function of temperature, with a value of $3 \times 10^{-7} \mathrm{~m}^{2} \mathrm{~s}^{-1}$ at $800{ }^{\circ} \mathrm{C}$ (Bagdassarov et al., 1994); internal heat transfer by convection or radiation can be neglected (Hort and Gardner, 2000). This yields $2 \mathrm{~h}$ for a $30-\mathrm{cm}$ pumice, which is consistent with the authors' observations (THD) that dm-sized pumices were only warm to the touch a day after emplacement. The value for a $1-\mathrm{m}$ pumice is $\sim 20 \mathrm{~h}$, so that static coalescence may have continued as long as a day in the largest pumices. These estimates ignore premature cooling by rain. Any air circulation was insufficient to oxidize the hot clast interiors during cooling (Tait et al., 1998). 


\subsection{Eruptive model}

The results are now placed in the context of the eruptive model proposed in previous papers ([Druitt et al., 2002], [Melnik and Sparks, 2002], [Clarke et al., 2002], [Formenti et al., 2003], [Diller et al., 2006] and [Clarke et al., 2007], Burgisser et al., in press) and illustrated in Fig. 15.

Magma ascended by viscous flow during the 3-63 h between explosions. The mean ascent velocity during this time was $\geq 0.02 \mathrm{~m} \mathrm{~s}^{-1}$, corresponding to a magmastatic decompression rate of $0.001-0.005 \mathrm{MPa} \mathrm{s}^{-1}$. Many large vesicles in the pumices may represent bubbles nucleated between explosions, the number densities of large vesicles being consistent (via Eq. (1)) with nucleation at such decompression rates. Other large vesicles may be the coalesced remnants of bubbles nucleated at higher number densities during previous explosions. Inter-explosion coalescence generated the permeability necessary for gas escape from the ascending magma, as reflected in the low water contents of groundmass glasses in dense pumices, breadcrust bombs and glassy lava fragments (Burgisser et al., in press). Possible relict gas-escape paths are preserved in dense pumices as interconnected networks of large, partially collapsed vesicles. Alternating bands of variable vesicularity in some flowbanded dense pumices and finely breadcrusted bombs may record the process of densification induced by differential outgassing, quenched in progress. Immediately prior to an average explosion, the conduit consisted of a deep, homogeneous, gas-rich zone with $<55$ vol. $\%$ voidage overlain by an impermeable, degassed, microlite-rich and rheologically stiffened plug, behind which gas pressure accumulated in a transition region of partly degassed magma (Diller et al., 2006; Burgisser et al., in press; Fig. 15a).

Plug rupture occurred once overpressure exceeded a critical threshold, probably of a few MPa or more ([Druitt et al., 2002], [Spieler et al., 2004b] and [Burgisser et al., in press]).

Decompression caused upward expansion, acceleration, fragmentation and eruption of the conduit contents ([Melnik and Sparks, 2002] and [Mason et al., 2006]). Coarsely breadcrusted bombs, finely breadcrusted bombs, dense pumices and light pumices form a continuous assemblage, the textural features of which can be understood by differences in the relative timing of initial decompression, fragmentation, and surface and interior quench. Largely degassed, non-vesicular, microlite-rich magma of the upper part of the plug underwent decompressions of a few MPa and entered the atmosphere immediately after fragmentation. Cooling during flight limited bubble growth in surface layers, whereas the hotter interiors frothed up, cracking the outer rind and breaking amphibole phenocrysts. These clasts, characterized by a large vesicularity difference between core and rind, form the coarsely breadcrusted bombs (Fig. 15b). Dense magma fragments from deeper in the plug followed a similar history, but the time interval between decompression and discharge was slightly longer, allowing more bubble growth in the surface rind prior to quench. The vesicularity contrast between surfaces and cores of the finely breadcrusted bombs is therefore smaller. Some coarsely breadcrusted bombs that broke either during ballistic impact or transport in pyroclastic flows developed finely breadcrusted surfaces on breakage surfaces. In all bombs, core inflation and surface breadcrusting was complete long before pyroclastic flows came to rest.

The time interval between decompression and discharge of the deep, gas-rich magma was sufficiently long that syn-explosive inflation was complete prior to surface quench (Fig. 15c). This accounts for the lack of surface breadcrusting, the apparent lack of dependence of vesicle textures on clast size (up to $\sim 30 \mathrm{~cm}$ ), and the textural similarities between flow and fallout 
pumices, despite different thermal histories after leaving the vent. It also allowed coalescence of newly formed bubbles to proceed further than in the breadcrust bombs. As pumices inflated, many amphibole phenocrysts were broken in a manner suggestive of isotropic decompression in parcels of fragmented magma. However uniaxial, flow-foliation-parallel boudinage of amphiboles implies that syn-explosive vesiculation of many pumices, possibly those from deeper in the conduit, was essentially complete even prior to fragmentation.

Syn-explosive bubble nucleation at all levels of the conduit took place heterogeneously on titanomagnetite. Growth took place under disequilibrium conditions largely by decompression-driven expansion; diffusive outgassing of melt was limited by the short timescale of the explosions, accounting for the high water contents preserved in groundmass glasses.

Decompression rates estimated from heterogeneously nucleated vesicle number densities (at least $0.3-6.5 \mathrm{MPa} \mathrm{s}^{-1}$ ) are an order of magnitude lower than if homogeneous nucleation were assumed (e.g. Toramaru, 2006, Hamada et al., in press). However they may be underestimated if there was insufficient time for bubble numbers to reach stationary values. Plug rupture during Vulcanian eruptions generates a downward-propagating rarefaction wave, followed by a slower fragmentation front (Melnik and Sparks, 2002), the ascent speed of the bubbly magma being a great deal slower than either. A zone of steep pressure gradient develops beneath the fragmentation front due to the discontinuous pressure change at the fragmentation surface and wall friction (Koyaguchi et al., 2008). Individual parcels of magma in an average Montserrat explosion simulated by Melnik and Sparks (2002; their Fig. 4) experience decompression rates of $\sim 1$ to $>20 \mathrm{MPa} \mathrm{s}^{-1}$ as they approach, then pass through, the descending fragmentation front. These values are of the same order of magnitude as those estimated from vesicle number densities, showing that there is no incompatibility between observations and models. They are consistent with the idea that syn-explosive bubble nucleation during the 1997 explosions was initiated during rapid decompression of conduit magma in a zone of steep pressure gradient beneath the descending fragmentation front.

\section{Acknowledgments}

The project was partly funded by the French Agence Nationale de la Recherche (ANREXPLANT, Contract No ANR-05-CATT-003 to C. Martel). We benefited from discussions with Stéphane Poussineau, Nicolas Cluzel, Karim Kelfoun, Thomas Shea, Lucia Gurioli, Didier Laporte, Jean-Louis Bourdier and Jim Gardner. Marc Leblanc gave us access to the He pycnometer, and Jean-Marc Hénot helped us use the SEM. We thank Amanda Clarke and Oliver Spieler for their thoughtful and constructive reviews of the manuscript.

\section{References}

Adams et al., 2006 N.K. Adams, B.F. Houghton and W. Hildreth, Abrupt transitions during sustained explosive eruptions: examples from the 1912 eruption of Novarupta, Alaska, Bull. Volcanol. 69 (2006), pp. 189-206. 
Bagdassarov et al., 1994 N.S. Bagdassarov, D.B. Dingwell and S.L. Webb, Viscoelasticity of crystal- and bubble-bearing rhyolite melts, Phys. Earth Planet. Inter. 83 (1994), pp. 83-89.

Barclay et al., 1998 J. Barclay, M.J. Rutherford, M.R. Carroll, M.D. Murphy, J.D. Devine, J. Gardner and R.S.J. Sparks, Experimental phase equilibria constraints on pre-eruptive storage conditions of the Soufrière Hills magma, Geophys. Res. Lett. 25 (18) (1998), pp. 3437-3440.

Behrens et al., 2004 H. Behrens, Y. Zhang and Z. Xu, $\mathrm{H}_{2} \mathrm{O}$ diffusion in dacitic and andesitic melts, Geochim. Cosmochim. Acta 68 (2004), pp. 5139-5150.

Blower et al., 2001 J.D. Blower, J.P. Keating, H.M. Mader and J.C. Phillips, Inferring degassing processes from vesicle size distributions, Geophys. Res. Lett. 28 (2001), pp. $347-$ 350 .

Burgisser and Gardner, 2005 A. Burgisser and J.E. Gardner, Experimental constraints on degassing and permeability in volcanic conduit flow, Bull. Volcanol. 67 (2005), pp. 42-56.

Burgisser et al., in press Burgisser, A., Poussineau, S., Arbaret, L., Druitt, T.H., Giachetti, T., Bourdier, J.L., in press. Pre-explosive conduit conditions of the 1997 Vulcanian explosions at Soufrière Hills Volcano, Montserrat: I. Pressure and vesicularity distributions. J. Volcanol. Geotherm. Res.

Carslaw and Jaeger, 1959 H.S. Carslaw and J.C. Jaeger, Conduction of Heat in Solids (2nd Edition), Clarendon Press, Oxford (1959).

Cheng and Lemlich, 1983 H.C. Cheng and R. Lemlich, Errors in the measurement of bubblesize distribution in foam, Ind. Eng. Chem. Fundam. 22 (1983), pp. 105-109.

Clarke et al., 2002 A.B. Clarke, A. Neri, B. Voight, G. Macedonio and T.H. Druitt, Computational modelling of the transient dynamics of the August 1997 Vulcanian explosions at Soufrière Hills Volcano, Montserrat; influence of initial conduit conditions on near-vent pyroclastic dispersal. In: T.H. Druitt and B.P. Kokelaar, Editors, The Eruption of Soufrière Hills Volcano, Montserrat, from 1995 to 1999, Geological Society of London Memoir vol. 21 (2002), pp. 319-348.

Clarke et al., 2007 A.B. Clarke, S. Stephens, R. Teasdale, R.S.J. Sparks and K. Diller, Petrologic constraints on the decompression history of magma prior to Vulcanian explosions at the Soufrière Hills volcano, Montserrat, J. Volcanol. Geotherm. Res. 161 (2007), pp. 261274.

Cluzel et al., 2008 N. Cluzel, D. Laporte, A. Provost and I. Kannewischer, Kinetics of heterogeneous bubble nucleation in rhyolitic melts: implications for the number density of bubbles in volcanic conduits and for pumice textures, Contrib. Mineral. Petrol. 156 (2008), pp. $745-763$.

Cole et al., 2002 P.D. Cole, E.S. Calder, R.S.J. Sparks, A.B. Clarke, T.H. Druitt, S.R. Young, R.A. Herd, C.L. Harford and G.E. Norton, Deposits from dome-collapse and fountaincollapse pyroclastic flows at Soufrière Hills Volcano, Montserrat. In: T.H. Druitt and B.P. Kokelaar, Editors, The Eruption of Soufrière Hills Volcano, Montserrat, from 1995 to 1999, Geological Society of London Memoir vol. 21 (2002), pp. 231-262. 
Devine et al., 2003 J.D. Devine, M.J. Rutherford, G.E. Norton and S.R. Young, Magma storage region processes inferred from geochemistry of $\mathrm{Fe}-\mathrm{Ti}$ oxides in andesitic magma, Soufriere Hills Volcano, Montserrat, WI, J. Petrol. 44 (2003), pp. 1375-1400.

Dingwell, 1998 D.B. Dingwell, The glass transition in hydrous granitic melts, Phys. Earth Planet. Inter. 107 (1998), pp. 1-3.

Diller et al., 2006 K. Diller, A.B. Clarke, B. Voight and A. Neri, Mechanisms of conduit plug formation: implications for vulcanian explosions, Geophys. Res. Lett. 33 (2006), p. L20302.

Druitt et al., 2002 T.H. Druitt, S.R. Young, B.J. Baptie, C. Bonadonna, E.S. Calder, A.B. Clarke, P.D. Cole, C.L. Harford, R.A. Herd, R. Lockett, G. Ryan and B. Voight, Episodes of cyclic Vulcanian explosive activity with fountain collapse at Soufrière Hills Volcano, Montserrat. In: T.H. Druitt and B.P. Kokelaar, Editors, The Eruption of Soufrière Hills Volcano, Montserrat, from 1995 to 1999, Geological Society of London Memoir vol. 21 (2002), pp. 281-306.

Formenti and Druitt, 2003 Y. Formenti and T.H. Druitt, Vesicle connectivity in pyroclasts and implications for the fluidisation of fountain-collapse pyroclastic flows, Montserrat (West Indies), Earth Planet. Sci. Lett. 214 (2003), pp. 561-574.

Formenti et al., 2003 Y. Formenti, T.H. Druitt and K. Kelfoun, Characterisation of the 1997 Vulcanian explosions of Soufrière Hills Volcano, Montserrat, by video analysis, Bull. Volcanol. 65 (2003), pp. 587-605.

Gaonac'h et al., 1996a H. Gaonac'h, S. Lovejoy, J. Stix and D. Schertzer, A scaling growth model for bubbles in basaltic flows, Earth Planet. Sci. Lett. 139 (1996), pp. 395-409.

Gaonac'h et al., 1996b H. Gaonac'h, J. Stix and S. Lovejoy, Scaling effects on vesicles shape, size and heterogeneity of lavas from Mount Etna, J. Volcanol. Geotherm. Res. 74 (1996), pp. $131-153$.

Gardner, 2007 J.E. Gardner, Heterogeneous bubble nucleation in highly viscous silicate melts during instantaneous decompression from high pressure, Chem. Geol. 236 (2007), pp. 1-12.

Gardner and Denis, 2004 J.E. Gardner and M.-H. Denis, Heterogeneous bubble nucleation on Fe-Ti oxide crystals in high-silica rhyolitic melts, Geochim. Cosmochim. Acta 68 (2004), pp. $3587-3597$.

Gardner et al., 1996 J.E. Gardner, R.M.E. Thomas, C. Jaupart and S. Tait, Fragmentation of magma during Plinian volcanic eruptions, Bull. Volcanol. 58 (1996), pp. 144-162

Gardner et al., 1999 J.E. Gardner, M. Hilton and M.E.R. Carroll, Experimental constraints on degassing of magma: isothermal bubble growth during continuous decompression from high pressure, Earth Planet. Sci. Lett. 168 (1999), pp. 201-218

Gardner et al., 2000 J.E. Gardner, M. Hilton and M.E.R. Carroll, Bubble growth in highly viscous silicate melts during continuous decompression from high pressure, Geochim. Cosmochim. Acta 64 (2000), pp. 1473-1483. 
Gurioli et al., 2005 L. Gurioli, B. Houghton, K. Cashman and R. Cioni, Complex changes in eruption dynamics during the 79 AD eruption of Vesuvius, Bull. Volcanol. 67 (2005), pp. 144-162.

Hamada et al., in press Hamada, M., Laporte, D., Cluzel, N., Koga, K.T., Kawamoto, T., in press. Simulating bubble number density of rhyolitic pumices from Plinian eruptions: constraints from fast decompression experiments. Bull. Volcanol. doi:10.1007/s00445-010$\underline{0353-z}$.

Harford et al., 2003 C.L. Harford, R.S.J. Sparks and A.E. Fallick, Degassing at the Soufrière Hills Volcano, Montserrat, recorded in matrix glass compositions, J. Petrol. 44 (2003), pp. $1503-1523$.

Hess and Dingwell, 1996 K.U. Hess and D.B. Dingwell, Viscosities of hydrous leucogranitic melts: a non-Arrhenian model, Am. Mineral. 81 (1996), pp. 297-304.

Hort and Gardner, 2000 M. Hort and J.E. Gardner, Constraints on degassing of pumice clasts during plinian eruptions based on model calculations, J. Geophys. Res. 105 (2000), pp. 25981-26001.

Houghton et al., 2003 B.F. Houghton, B.J. Hobden, K.V. Cashman, C.J.N. Wilson and R.T. Smith, Large-scale interaction of lake water and rhyolitic magma during the 1.8 ka Taupo eruption, New Zealand. In: J.D.L. White, J.L. Smellie and D.A. Clague, Editors, Explosive Subaqueous Volcanism, Geophys. Monograph 140 (2003), pp. 97-109.

Hurwitz and Navon, 1994 S. Hurwitz and O. Navon, Bubble nucleation in rhyolitic melts: experiments at high pressures, temperature, and water content, Earth Planet. Sci. Lett. 122 (1994), pp. 267-280.

Kaminski and Jaupart, 1997 E. Kaminski and C. Jaupart, Expansion and quenching of vesicular magma fragments in Plinian eruptions, J. Geophys. Res. 102 (1997), pp. 1128712203.

Kennedy et al., 2005 B. Kennedy, O. Spieler, B. Scheu, U. Kueppers, J. Taddeucci and D.B. Dingwell, Conduit implosion during Vulcanian eruptions, Geology 33 (2005), pp. 581-584.

Klug and Cashman, 1991 C. Klug and K.V. Cashman, Effects of vesicle size and shape on the vesicularity of silicic magma fragmentation (abstract), EOS Trans. Am. Geophys. Union 72 (1991), p. 312.

Klug and Cashman, 1994 C. Klug and K.V. Cashman, Vesiculation of May 18, 1980, Mount St. Helens magma, Geology 22 (1994), pp. 468-472.

Klug and Cashman, 1996 C. Klug and K.V. Cashman, Permeability development in vesiculating magmas: implications for fragmentation, Bull. Volcanol. 58 (1996), pp. 87-100.

Klug et al., 2002 C. Klug, K.V. Cashman and C.R. Bacon, Structure and physical characteristics of pumice from the climatic eruption of Mount Mazama (Crater Lake), Oregon, Bull. Volcanol. 64 (2002), pp. 486-501. 
Koyaguchi et al., 2008 T. Koyaguchi, B. Scheu, N.K. Mitani and O. Melnik, A fragmentation criterion for highly viscous bubbly magmas estimated from shock tube experiments, $J$.

Volcanol. Geotherm. Res. 178 (2008), pp. 58-71.

Lantuéjoul, 1980 C. Lantuéjoul, On the estimation of mean values in individual analysis of particles, Microsc. Acta 5 (1980), pp. 266-273.

Larsen et al., 2004 J.F. Larsen, M.-H. Denis and J.E. Gardner, Experimental study of bubble coalescence in rhyolitic and phonolitic melts, Geochim. Cosmochim. Acta 68 (2004), pp. 333344.

Lensky et al., 2004 N.G. Lensky, O. Navon and V. Lyakhovsky, Bubble growth during decompression of magma: experimental and theoretical investigation, J. Volcanol. Geotherm. Res. 129 (2004), pp. 7-22.

Liu and Zhang, 2000 Y. Liu and Y. Zhang, Bubble growth in rhyolitic melt, Earth Planet. Sci. Lett. 181 (2000), pp. 251-264.

Lyakhovsky et al., 1996 V. Lyakhovsky, S. Hurwitz and O. Navon, Bubble growth in rhyolitic melts: experimental and numerical investigation, Bull. Volcanol. 58 (1996), pp. 1932.

Mangan and Sisson, 2000 M.T. Mangan and T.W. Sisson, Delayed, disequilibrium degassing in rhyolite magma: decompression experiments and implications for explosive volcanism, Earth Planet. Sci. Lett. 183 (2000), pp. 441-455.

Mangan et al., 1993 M.T. Mangan, K.V. Cashman and S. Newman, Vesiculation of basaltic magma during eruption, Geology 21 (1993), pp. 157-160.

Mangan et al., 2004 M.T. Mangan, T.W. Sisson and W.B. Hankins, Decompression experiments identify kinetics controls on explosive silicic eruptions, Geophys. Res. Lett. 31 (2004), p. L08605.

Mason et al., 2006 R.M. Mason, A.B. Starostin, O.E. Melnik and R.S.J. Sparks, From Vulcanian explosions to sustained explosive eruptions: the role of diffusive mass transfer in conduit flow dynamics, J. Volcanol. Geotherm. Res. 153 (2006), pp. 148-165.

Massol and Koyaguchi, 2005 H. Massol and T. Koyaguchi, The effect of magma flow on nucleation of gas bubbles in a volcanic conduit, J. Volcanol. Geotherm. Res. 143 (2005), pp. 69-88.

Melnik and Sparks, 2002 O. Melnik and R.S.J. Sparks, Modelling of conduit flow dynamics during explosive activity at Soufrière Hills Volcano, Montserrat. In: T.H. Druitt and B.P. Kokelaar, Editors, The Eruption of Soufrière Hills Volcano, Montserrat, from 1995 to 1999, Geological Society of London Memoir vol. 21 (2002), pp. 307-317.

Miles, 1974 R. Miles, Stochastic Geometry, on the Elimination of Edge Effects in Planar Sampling, J. Wiley and Sons, New York (1974). 
Mourtada-Bonnefoi and Laporte, 1999 C.C. Mourtada-Bonnefoi and D. Laporte, Experimental study of homogeneous bubble nucleation in rhyolitic magmas, Geophys. Res. Lett. 26 (1999), pp. 3505-3508.

Mourtada-Bonnefoi and Laporte, 2002 C.C. Mourtada-Bonnefoi and D. Laporte, Homogeneous bubble nucleation in rhyolitic magmas: an experimental study of the effect of $\mathrm{H}_{2} \mathrm{O}$ and $\mathrm{CO}_{2}$, J. Geophys. Res. 107 (2002), p. 101029.

Mourtada-Bonnefoi and Laporte, 2004 C.C. Mourtada-Bonnefoi and D. Laporte, Kinetics of bubble nucleation in rhyolitic melt: an experimental investigation of the effect of ascent rate, Earth Planet. Sci. Lett. 218 (2004), p. 521-237.

Murphy et al., 1998 M.D. Murphy, R.S.J. Sparks, J. Barclay, M.R. Carroll, A.M. Lejeune, T.S. Brewer, R. McDonald, S. Black and S. Young, The role of magma mixing in triggering the current eruption of the Soufrière Hills volcano, Montserrat, West Indies, Geophys. Res. Lett. 25 (1998), pp. 3433-3436.

Navon and Lyakhovsky, 1998 O. Navon and V. Lyakhovsky, Vesiculation processes in silicic magmas. The physics of explosive volcanic eruptions, Geol. Soc. Lond. Spec. Publ. 145 (1998), pp. 27-50.

Orsi et al., 1992 G. Orsi, G. Gallo, H. Heiken, K. Wohletz, E. Yu and G. Bonani, A comprehensive study of pumice formation and dispersal: the Cretaio Tephra of Ischia Italy, $J$. Volcanol. Geotherm. Res. 53 (1992), pp. 329-354.

Proussevitch and Sahagian, 1996 A.A. Proussevitch and D.L. Sahagian, Dynamics of coupled diffusive and compressive bubble growth in magmatic systems, J. Geophys. Res. 101 (1996), pp. 17447-17455.

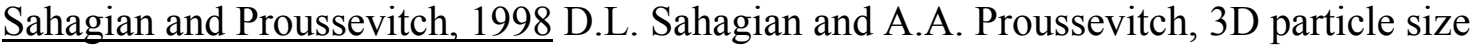
distributions from 2D observations: stereology for natural applications, J. Volcanol. Geotherm. Res. 84 (1998), pp. 173-196.

Shea et al., 2010 T. Shea, B.F. Houghton, L. Gurioli, K.V. Cashman, J.E. Hammer and B.J. Hobden, Textural studies of vesicles in volcanic rocks: an integrated methodology, $J$. Volcanol. Geotherm. Res. 190 (2010), pp. 271-289.

Sparks, 1978 R.S.J. Sparks, The dynamics of bubble formation and growth in magmas: a review and analysis, J. Volcanol. Geotherm. Res. 3 (1978), pp. 1-37.

Spieler et al., 2004a O. Spieler, D.B. Dingwell and M. Alidibirov, Magma fragmentation speed: an experimental determination, J. Volcanol. Geotherm. Res. 129 (2004), pp. 109-123.

Spieler et al., 2004b O. Spieler, B. Kennedy, U. Kueppers, D.B. Dingwell, B. Scheu and J. Taddeucci, The fragmentation threshold of pyroclastic rocks, Earth Planet. Sci. Lett. 226 (12) (2004), pp. 139-148.

Tait et al., 1998 S. Tait, R. Thomas, J. Gardner and C. Jaupart, Constraints on cooling rates and permeabilities of pumice in an explosive eruption jet from colour and magnetic mineralogy, J. Volcanol. Geotherm. Res. 86 (1998), pp. 79-91. 
Thomas et al., 1994 N. Thomas, C. Jaupart and S. Vergniolle, On the vesicularity of pumice, $J$. Geophys. Res. 99 (1994), pp. 15633-15644.

Toramaru, 1990 A. Toramaru, Measurement of bubble size distributions in vesiculated rocks with implications for quantitative estimates of eruption processes, J. Volcanol. Geotherm. Res. 43 (1990), pp. 71-90.

Toramaru, 2006 A. Toramaru, BND (bubble number density) decompression rate meter for explosive volcanic eruptions, J. Volcanol. Geotherm. Res. 154 (2006), pp. 303-316

Walker, 1982 G. Walker, Eruptions of andesitic volcanoes. In: R.S. Thorpe, Editor, Andesites: Orogenic Andesites and Related Rocks, Wiley, New York (1982), pp. 403-413.

Westrich and Eichelberger, 1994 H.R. Westrich and J.C. Eichelberger, Gas transport and bubble collapse in rhyolite magma: an experimental approach, Bull. Volcanol. 56 (1994), pp. $447-458$.

Whitham and Sparks, 1986 A.G. Whitham and R.S.J. Sparks, Pumice, Bull. Volcanol. 48 (1986), pp. 209-223.

Wright et al., 2007 H.M.N. Wright, K.V. Cashman, M. Rosi and R. Cioni, Breadcrust bombs as indicators of Vulcanian eruption dynamics at Guagua Pichincha volcano, Ecuador. Bull. Volcanol. 69 (2007), pp. 281-300.

Zhang and Behrens, 2000 Y. Zhang and $\mathrm{H}$. Behrens, $\mathrm{H}_{2} \mathrm{O}$ diffusion in rhyolitic melts and glasses, Chem. Geol. 169 (2000), pp. 243-262. 


\section{Appendix A. Size-distribution measurement of vesicles and crystals}

Size distributions were measured using images of six overlapping magnifications: (1) 2 images of a thin section and/or cut hand specimen, (2) 2 SEM images at $\times 27$, (3) 2 SEM images at $\times 100$, (4) 4 SEM images at $\times 200$, (5) 4 SEM images at $\times 500$, and (6) 6 SEM images at $\times 1500$. Vesicles or crystals (referred to hereon as 'objects') of $>300 \mu \mathrm{m}$ were counted at magnification 1 , and those of $<300 \mu \mathrm{m}$ were measured at magnifications $2-6$. Size distributions were constructed in four steps as follows:

Step 1. Size distribution for each image. Each image resulted in three binary images (isolated vesicles, connected vesicles, and crystals), which were analysed with the ImageJ imageanalysis software. Using the surface area $A$ and the scale of the image, an equivalent diameter $D$ was calculated for each object (assuming circular shape), and surface area and area number distributions were calculated as functions of $D$. The probability of a large object being intersected by the edge of the image is larger than that of a small object, and we applied the corrections of

(Miles, 1974)

and

(Lantuéjoul, 1980)

to obtain the true number of objects $\left(N_{a}\right)$.

Step 2. Size distribution for each magnification. The object size distribution for a given magnification was obtained by averaging those of the separate images for that magnification. This resulted in averaging any heterogeneity in object size or shape distribution present on the microscopic scale, assuming that possible shape variations were randomly oriented. Tests on multiple areas of single pyroclasts showed that this assumption was valid to a first approximation.

Step 3. Size distribution for the whole sample. This third stage generated an object-size distribution for the whole sample using the individual distributions at each magnification. Some studies perform this step using $N_{a}$ (

[Shea et al., 2010]

Klug and Cashman, 1994$]$

and

[Klug et al., 2002]

), whereas we used object surface areas. We first defined cut-off limits between magnifications, being chosen so that each object had a diameter of at least 15 pixels and was no larger than $10 \%$ of the image size (in order to be statistically represented). The limits correspond to $\log D$ values of 2.5, 2.0, 1.6, 1.2 and 0.8 , from lowest to highest magnifications, as shown on

Fig. 10

.We then normalised the data at each magnification to the surface area of the lowest magnification, correcting at each magnification for objects larger than the cut-off limits previously defined. This correction was applied starting at the lowest magnification and working progressively upwards. Surface and number distributions were then obtained for the whole sample. In total 930-4750 crystals and 3390-9620 vesicles were measured for each sample. Full explanation and worked examples are available from the first author on request. 
Step 4. $2 D-3 D$ conversions. Two-dimensional data ( $N_{a}$ and surface distribution) were then converted to 3D ( $N_{v}$ and volume distribution). Since we chose samples with spherical and homogeneously distributed vesicles (at least to the eye), we assumed that the area distribution obtained directly equals the volume distribution. Our method has the advantage of directly providing the total sample vesicularity by integrating the vesicle-volume distribution. Values thus obtained were close to those from He-pycnometry (

\section{$\underline{\text { Table } 1}$}

), convincing us of the accuracy of our method. Two methods were used to convert $N_{a}$ to $N_{v}$. Cheng and Lemlich, 1983 H.C. Cheng and R. Lemlich, Errors in the measurement of bubblesize distribution in foam, Ind. Eng. Chem. Fundam. 22 (1983), pp. 105-109. Cheng and Lemlich (1983)

proposed a conversion: $N_{v}=N_{a} / D_{m}$, where $D_{m}$ is the average equivalent diameter of each size class. This method is easy to apply and involves no assumptions of object shape.

However, it does not take into account the cut effect, which is corrected by the method of Sahagian and Proussevitch (1998)

, assuming spherical shapes. Our results showed that object number densities obtained from the two methods were the same to within $15 \%$, and mostly within $5 \%$ (

$\underline{\text { Table } 1}$

). Number density distributions were also very similar. However, since the method of Sahagian and Proussevitch (1998)

sometimes generates negative values of $N_{v}$ for some size classes, values used in the text are those obtained using the method of

Cheng and Lemlich (1983) 
Figures and Tables 
Table 1. Results of textural analysis of explosion pyroclasts.

\begin{tabular}{|c|c|c|c|c|c|c|c|c|c|}
\hline & & BCP1 rind & BCP43 rind & BCP1 core & BCP43 core & AMO29 & AMO36 & PV3 & $\mathbf{R} 2$ \\
\hline \multicolumn{2}{|l|}{ Sample type } & $\begin{array}{l}\text { Coarsely } \\
\text { breadcrusted } \\
\text { bomb rind }\end{array}$ & $\begin{array}{l}\text { Finely } \\
\text { breadcrusted } \\
\text { bomb rind }\end{array}$ & $\begin{array}{l}\text { Coarsely } \\
\text { breadcrusted } \\
\text { bomb core }\end{array}$ & $\begin{array}{l}\text { Finely } \\
\text { breadcrusted } \\
\text { bomb core }\end{array}$ & $\begin{array}{l}\text { Pyroclastic } \\
\text { flow pumice } \\
\text { (dense) }\end{array}$ & $\begin{array}{l}\text { Pyroclastic } \\
\text { flow pumice } \\
\text { (dense) }\end{array}$ & $\begin{array}{l}\text { Pyroclastic } \\
\text { flow pumice } \\
\text { (highly } \\
\text { vesicular) }\end{array}$ & $\begin{array}{l}\text { Fallout } \\
\text { pumice } \\
\text { (dense) }\end{array}$ \\
\hline \multicolumn{2}{|c|}{$\begin{array}{l}\text { Bulk vesicularity - He-pycnometry } \\
\text { (vol.\%) }\end{array}$} & $8 \pm 2$ & $12 \pm 2$ & $33 \pm 2$ & $49 \pm 1$ & $58 \pm 1$ & $61 \pm 1$ & $76 \pm 1$ & - \\
\hline \multicolumn{2}{|c|}{ Isolated fraction - He-pycnometry ${ }^{a}$} & 1.00 & - & 0.33 & 0.13 & 0.15 & 0.09 & 0.09 & - \\
\hline \multicolumn{2}{|c|}{$\begin{array}{l}\text { Bulk vesicularity — image analysis } \\
\text { (vol.\%) }\end{array}$} & $9 \pm 2$ & $9 \pm 2$ & $36 \pm 2$ & $48 \pm 2$ & $61 \pm 2$ & $57 \pm 2$ & $74 \pm 2$ & $56 \pm 2$ \\
\hline \multicolumn{2}{|c|}{ Isolated fraction — image analysis ${ }^{\mathrm{a}}$} & 0.13 & 0.37 & 0.23 & 0.46 & 0.09 & 0.07 & 0.11 & 0.17 \\
\hline \multicolumn{2}{|c|}{$\begin{array}{l}\text { Crystallinity vesicle-free - image } \\
\text { analysis (vol.\%) }\end{array}$} & 54 & 59 & 79 & 54 & 73 & 66 & 55 & 69 \\
\hline \multicolumn{2}{|c|}{ Glass — image analysis (vol.\%) } & 46 & 41 & 21 & 46 & 27 & 34 & 45 & 31 \\
\hline \multirow[t]{3}{*}{$\begin{array}{l}\text { Modes of vesicle } \\
\text { populations. }^{\text {b }}(\mu \mathrm{m})\end{array}$} & Small & 10 & 14 & 20 & 20 & 23 & 16 & 24 & 13 \\
\hline & Intermediate & - & - & - & 142 & 82 & 40 & 135 & 80 \\
\hline & Large & 1273 & 455 & 1221 & 2299 & 1879 & 735 & 2145 & 1432 \\
\hline \multirow{3}{*}{$\begin{array}{l}\text { Proportions of } \\
\text { vesicle populations. } \\
\text { (vol.\% of bulk } \\
\text { vesicularity) }\end{array}$} & Small & 15 & 37 & 62 & 71 & 40 & 42 & 38 & 53 \\
\hline & Intermediate & - & - & - & 9 & 31 & 44 & 25 & 34 \\
\hline & Large & 85 & 63 & 38 & 20 & 29 & 12 & 37 & 13 \\
\hline $\begin{array}{l}N_{v} \text { all vesicles } \\
\left(\times 10^{14} \mathrm{~m}^{-3} \text { of }\right.\end{array}$ & $\begin{array}{l}\text { Cheng and } \\
\text { Lemlich (1983) }\end{array}$ & $9.5 \pm 0.4$ & $26.2 \pm 1.1$ & $22.6 \pm 1.2$ & $48.0 \pm 2.8$ & $15.9 \pm 1.0$ & $31.1 \pm 3.7$ & $23.9 \pm 2.0$ & $66.8 \pm 4.9$ \\
\hline
\end{tabular}




\begin{tabular}{|c|c|c|c|c|c|c|c|c|c|}
\hline & & BCP1 rind & BCP43 rind & BCP1 core & BCP43 core & AMO29 & АMO36 & PV3 & R2 \\
\hline \multicolumn{2}{|l|}{ Sample type } & $\begin{array}{l}\text { Coarsely } \\
\text { breadcrusted } \\
\text { bomb rind }\end{array}$ & $\begin{array}{l}\text { Finely } \\
\text { breadcrusted } \\
\text { bomb rind }\end{array}$ & $\begin{array}{l}\text { Coarsely } \\
\text { breadcrusted } \\
\text { bomb core }\end{array}$ & $\begin{array}{l}\text { Finely } \\
\text { breadcrusted } \\
\text { bomb core }\end{array}$ & $\begin{array}{l}\text { Pyroclastic } \\
\text { flow pumice } \\
\text { (dense) }\end{array}$ & $\begin{array}{l}\text { Pyroclastic } \\
\text { flow pumice } \\
\text { (dense) }\end{array}$ & $\begin{array}{l}\text { Pyroclastic } \\
\text { flow pumice } \\
\text { (highly } \\
\text { vesicular) }\end{array}$ & $\begin{array}{l}\text { Fallout } \\
\text { pumice } \\
\text { (dense) }\end{array}$ \\
\hline \multicolumn{10}{|l|}{ glass $)^{\mathrm{c}}$} \\
\hline $\begin{array}{l}N_{v} \text { connected } \\
\text { vesicles }\left(\times 10^{14} \mathrm{~m}^{-3}\right. \\
\text { of glass })^{\mathrm{c}}\end{array}$ & & $0.0 \pm 0.0$ & $0.0 \pm 0.0$ & $17.9 \pm 1.0$ & $18.6 \pm 1.2$ & $7.5 \pm 0.6$ & $22.9 \pm 3.4$ & $17.8 \pm 1.4$ & $48.8 \pm 4.1$ \\
\hline $\begin{array}{l}N_{v} \text { isolated vesicles } \\
\left(\times 10^{14} \mathrm{~m}^{-3} \text { of }\right. \\
\text { glass })^{\mathrm{c}}\end{array}$ & & $9.5 \pm 0.4$ & $26.2 \pm 1.1$ & $4.6 \pm 0.2$ & $29.4 \pm 1.6$ & $8.3 \pm 0.4$ & $8.2 \pm 0.3$ & $6.1 \pm 0.7$ & $18.0 \pm 0$. \\
\hline $\begin{array}{l}N_{v} \text { crystals } \\
\left(\times 10^{14} \mathrm{~m}^{-3} \text { of }\right. \\
\text { glass })^{\mathrm{c}}\end{array}$ & & $139 \pm 4$ & $162 \pm 4$ & $357 \pm 9$ & $137 \pm 4$ & $177 \pm .5$ & $170 \pm 4$ & $131 \pm 3$ & $357 \pm 8$ \\
\hline $\begin{array}{l}N_{v} \text { oxides } \\
\left(\times 10^{14} \mathrm{~m}^{-3} \text { of }\right. \\
\text { glass })^{\mathrm{c}}\end{array}$ & & $83 \pm 2$ & $101 \pm 3$ & $174 \pm 5$ & $89 \pm 3$ & $77 \pm 2$ & $82 \pm 2$ & $97 \pm 2$ & $163 \pm 4$ \\
\hline $\begin{array}{l}N_{v} \text { all vesicles } \\
\left(\times 10^{14} \mathrm{~m}^{-3} \text { of }\right. \\
\text { glass })^{\mathrm{c}}\end{array}$ & $\begin{array}{l}\text { Sahagian and } \\
\text { Proussevitch } \\
\text { (1998) }\end{array}$ & $9.9 \pm 0.4$ & $26.8 \pm 1.1$ & $21.7 \pm 1.3$ & $43.4 \pm 3.0$ & $15.9 \pm 1.1$ & $27.8 \pm 4.3$ & $25.7 \pm 2.5$ & $57.5 \pm 5.1$ \\
\hline $\begin{array}{l}N_{v} \text { connected } \\
\text { vesicles }\left(\times 10^{14} \mathrm{~m}^{-3}\right. \\
\text { of glass })^{\mathrm{c}}\end{array}$ & & $0.0 \pm 0.0$ & $0.0 \pm 0.0$ & $17.1 \pm 1.1$ & $18.0 \pm 1.3$ & $7.4 \pm 0.6$ & $20.2 \pm 4.0$ & $19.1 \pm 1.7$ & $41.2 \pm 4.2$ \\
\hline $\begin{array}{l}N_{v} \text { isolated vesicles } \\
\left(\times 10^{14} \mathrm{~m}^{-3} \text { of }\right. \\
\text { glass })^{\mathrm{c}}\end{array}$ & & $9.9 \pm 0.4$ & $26.8 \pm 1.1$ & $4.6 \pm 0.2$ & $25.4 \pm 1.7$ & $8.5 \pm 0.5$ & $7.6 \pm 0.3$ & $6.6 \pm 0.9$ & $16.3 \pm 0$. \\
\hline $\begin{array}{l}N_{v} \text { crystals } \\
\left(\times 10^{14} \mathrm{~m}^{-3} \text { of }\right. \\
\text { glass })^{\mathrm{c}}\end{array}$ & & $147 \pm 3$ & $163 \pm 3$ & $413 \pm 6$ & $142 \pm 3$ & $177 \pm .4$ & $182 \pm 3$ & $143 \pm 2$ & $407 \pm 6$ \\
\hline
\end{tabular}




\begin{tabular}{|c|c|c|c|c|c|c|c|c|c|}
\hline & & BCP1 rind & BCP43 rind & BCP1 core & BCP43 core & AMO29 & AMO36 & PV3 & $\mathbf{R} 2$ \\
\hline \multicolumn{2}{|l|}{ Sample type } & $\begin{array}{l}\text { Coarsely } \\
\text { breadcrusted } \\
\text { bomb rind }\end{array}$ & $\begin{array}{l}\text { Finely } \\
\text { breadcrusted } \\
\text { bomb rind }\end{array}$ & $\begin{array}{l}\text { Coarsely } \\
\text { breadcrusted } \\
\text { bomb core }\end{array}$ & $\begin{array}{l}\text { Finely } \\
\text { breadcrusted } \\
\text { bomb core }\end{array}$ & $\begin{array}{l}\text { Pyroclastic } \\
\text { flow pumice } \\
\text { (dense) }\end{array}$ & $\begin{array}{l}\text { Pyroclastic } \\
\text { flow pumice } \\
\text { (dense) }\end{array}$ & $\begin{array}{l}\text { Pyroclastic } \\
\text { flow pumice } \\
\text { (highly } \\
\text { vesicular) }\end{array}$ & $\begin{array}{l}\text { Fallout } \\
\text { pumice } \\
\text { (dense) }\end{array}$ \\
\hline $\begin{array}{l}N_{v} \text { oxides } \\
\left(\times 10^{14} \mathrm{~m}^{-3} \text { of }\right. \\
\text { glass })^{\mathrm{c}}\end{array}$ & & $96 \pm 1$ & $113 \pm 2$ & $208 \pm 3$ & $101 \pm 2$ & $78 \pm 1$ & $95 \pm 1$ & $112 \pm 1$ & $198 \pm 3$ \\
\hline \multirow{3}{*}{$\begin{array}{l}\text { Vesicles number of } \\
\text { each population. } \\
\left(\mathrm{m}^{-3} \text { of melt }\right)\end{array}$} & Small & $9.5 \times 10^{14}$ & $26.2 \times 10^{14}$ & $22.6 \times 10^{14}$ & $48.0 \times 10^{14}$ & $15.7 \times 10^{14}$ & $30.8 \times 10^{14}$ & $23.9 \times 10^{14}$ & $66.6 \times 10^{14}$ \\
\hline & Intermediate & - & - & - & $1.1 \times 10^{11}$ & $1.4 \times 10^{13}$ & $3.8 \times 10^{13}$ & $0.4 \times 10^{13}$ & $1.2 \times 10^{13}$ \\
\hline & Large & $1.5 \times 10^{10}$ & $2.5 \times 10^{10}$ & $8.3 \times 10^{10}$ & $3.3 \times 10^{8}$ & $2.1 \times 10^{9}$ & $9.9 \times 10^{9}$ & $9.0 \times 10^{9}$ & $2.3 \times 10^{9}$ \\
\hline \multicolumn{2}{|l|}{ Fractal dimension } & -1.9 & -2.3 & -2.7 & -2.8 & -3.1 & -3.4 & -2.9 & -3.3 \\
\hline \multicolumn{2}{|c|}{$\mathrm{H}_{2} \mathrm{O}$ in residual glass (wt.\%) ${ }^{\mathrm{d}}$} & $0.83 \pm 0.13$ & - & $1.10 \pm 0.34$ & - & $0.45 \pm 0.31$ & $0.74 \pm 0.33$ & $1.32 \pm 0.14$ & $0.75 \pm 0.13^{\mathrm{e}}$ \\
\hline \multicolumn{2}{|c|}{$\begin{array}{l}\text { Quench pressures } P_{\text {sat }}(\mathrm{MPa}) \text { from } \mathrm{H}_{2} \mathrm{O} \\
\text { content }^{\mathrm{d}}\end{array}$} & $6.1 \pm 1.8$ & - & $10.3 \pm 5.9$ & - & $1.9 \pm 2.5$ & $4.9 \pm 4.1$ & $14.5 \pm 2.8$ & $5.0 \pm 1.5^{\mathrm{e}}$ \\
\hline \multicolumn{2}{|c|}{$\begin{array}{l}\text { Pre-explosive vesicularity (vol.\%) } \\
\text { estimated by }\end{array}$} & & & & & & & & \\
\hline \multicolumn{2}{|c|}{ - Vesicle size populations ${ }^{\mathrm{f}}$} & $<1$ & $<1$ & $<1$ & $<1$ & 28 & 11 & 47 & 12 \\
\hline \multicolumn{2}{|c|}{ - Recorded strain by amphiboles ${ }^{\mathrm{f}}$} & - & - & - & - & 35 & 27 & 57 & 27 \\
\hline
\end{tabular}

${ }^{\mathrm{a}}$ Isolated fraction $=$ isolated vesicularity/total vesicularity.

${ }^{\mathrm{b}}$ Determined using the KWare SFT software.

${ }^{\mathrm{c}}$ The errors assume measurements of vesicle numbers to within $\pm 5 \%$ on individual images.

${ }^{\mathrm{d}}$ From Burgisser et al. (in press).

${ }^{\mathrm{e}}$ Unpublished, from S. Poussineau (personal communication).

${ }^{\mathrm{f}}$ See text for explanation. 
Table 2. Estimation of timescales pertaining to vesicle growth in explosion pyroclasts.

\begin{tabular}{|c|c|c|c|c|}
\hline & $\begin{array}{l}\text { Breadcrust } \\
\text { bomb rind }\end{array}$ & $\begin{array}{l}\text { Breadcrust } \\
\text { bomb core }\end{array}$ & $\begin{array}{l}\text { Poorly } \\
\text { vesicular } \\
\text { pumice }\end{array}$ & $\begin{array}{l}\text { Highly } \\
\text { vesicular } \\
\text { pumice }\end{array}$ \\
\hline $\mathrm{H}_{2} \mathrm{O}$ in melt $(w t . \%)^{\mathrm{a}}$ & $0.6-1.0$ & $1.1-1.6$ & $0.5-2.0$ & $1.3-2.8$ \\
\hline Initial pressure $P_{\text {sat }}(\mathrm{MPa})^{\mathrm{a}}$ & $5-10$ & $5-10$ & $10-40$ & $15-65$ \\
\hline Temperature $T\left({ }^{\circ} \mathrm{C}\right)^{\mathrm{b}}$ & 700 & 850 & 850 & 850 \\
\hline $\begin{array}{l}\text { Diffusion coefficient } D \\
\left(\mathrm{~m}^{2} \mathrm{~s}^{-1}\right)^{\mathrm{c}}\end{array}$ & $\begin{array}{l}0.2- \\
0.5 \times 10^{-12}\end{array}$ & $\begin{array}{l}2.6- \\
4.8 \times 10^{-12}\end{array}$ & $\begin{array}{l}1.3- \\
5.8 \times 10^{-12}\end{array}$ & $\begin{array}{l}2.9- \\
7.7 \times 10^{-12}\end{array}$ \\
\hline $\begin{array}{l}\text { Bubble number density of } \\
\text { the small vesicle population } \\
N_{\text {stat }}\left(\mathrm{m}^{-3}\right)^{\underline{d}}\end{array}$ & $\begin{array}{l}8.4- \\
31.1 \times 10^{14}\end{array}$ & $\begin{array}{l}21.4- \\
50.8 \times 10^{14}\end{array}$ & $\begin{array}{l}14.9- \\
71.7 \times 10^{14}\end{array}$ & $\begin{array}{l}21.9- \\
25.9 \times 10^{14}\end{array}$ \\
\hline Viscosity $\eta(\mathrm{Pa} \mathrm{s})^{\mathrm{e}}$ & $3.7-45 \times 10^{9}$ & $1.4-4.8 \times 10^{6}$ & $0.7-52 \times 10^{6}$ & $0.2-2.8 \times 10^{6}$ \\
\hline $\begin{array}{l}\text { Decompression rate } \\
\left(\mathrm{MPa} \mathrm{s}^{-1}\right)^{\mathrm{c}}\end{array}$ & - & $1.3-5.4$ & $0.3-6.5$ & $0.8-3.9$ \\
\hline Decompression time $\tau_{d e c}(\mathrm{~s})^{\mathrm{f}}$ & 10 & 10 & $10-50$ & $10-50$ \\
\hline Viscous time $\tau_{v i s}(\mathrm{~s})^{\mathrm{f}}$ & $510-1780$ & $1-2$ & $0.3-5$ & $0.06-0.17$ \\
\hline Diffusion time $\tau_{d i f}(\mathrm{~s})^{6}$ & $30-72$ & $5-9$ & $4-20$ & $3-9$ \\
\hline
\end{tabular}

\footnotetext{
a Burgisser et al. (in press).

${ }^{\mathrm{b}}$ Harford et al. (2003). The temperature of the breadcrust bomb rind was arbitrary decreased by $150{ }^{\circ} \mathrm{C}$ to take into account the quenching by the atmosphere under the glass transition temperature.

${ }^{\mathrm{c}}$ Method of Toramaru (2006), using (Zhang and Behrens, 2000) and (Behrens et al., 2004), with $\mathrm{SiO}_{2}$ contents of 76 to $80 \mathrm{wt}$ \% for all samples (Barclay et al. 1998), $\sigma=0.025 \mathrm{~N} \mathrm{~m}^{-1}$ for heterogeneous nucleation (Cluzel et al., 2008) and the given melt water contents.

${ }^{\mathrm{d}}$ From Table 1, $N_{v}$ values of both BCP1 and BCP43 used for the breadcrust bomb core and rind, values of AMO36, AMO29 and R2 for the poorly vesicular pumice and values of PV3 for the highly vesicular pumice.

${ }^{\mathrm{e}}$ Hess and Dingwell (1996), $\eta$ calculated using given melt water contents.

${ }^{\mathrm{f}}$ Calculated following Lensky et al. (2004); see text for details.
} 


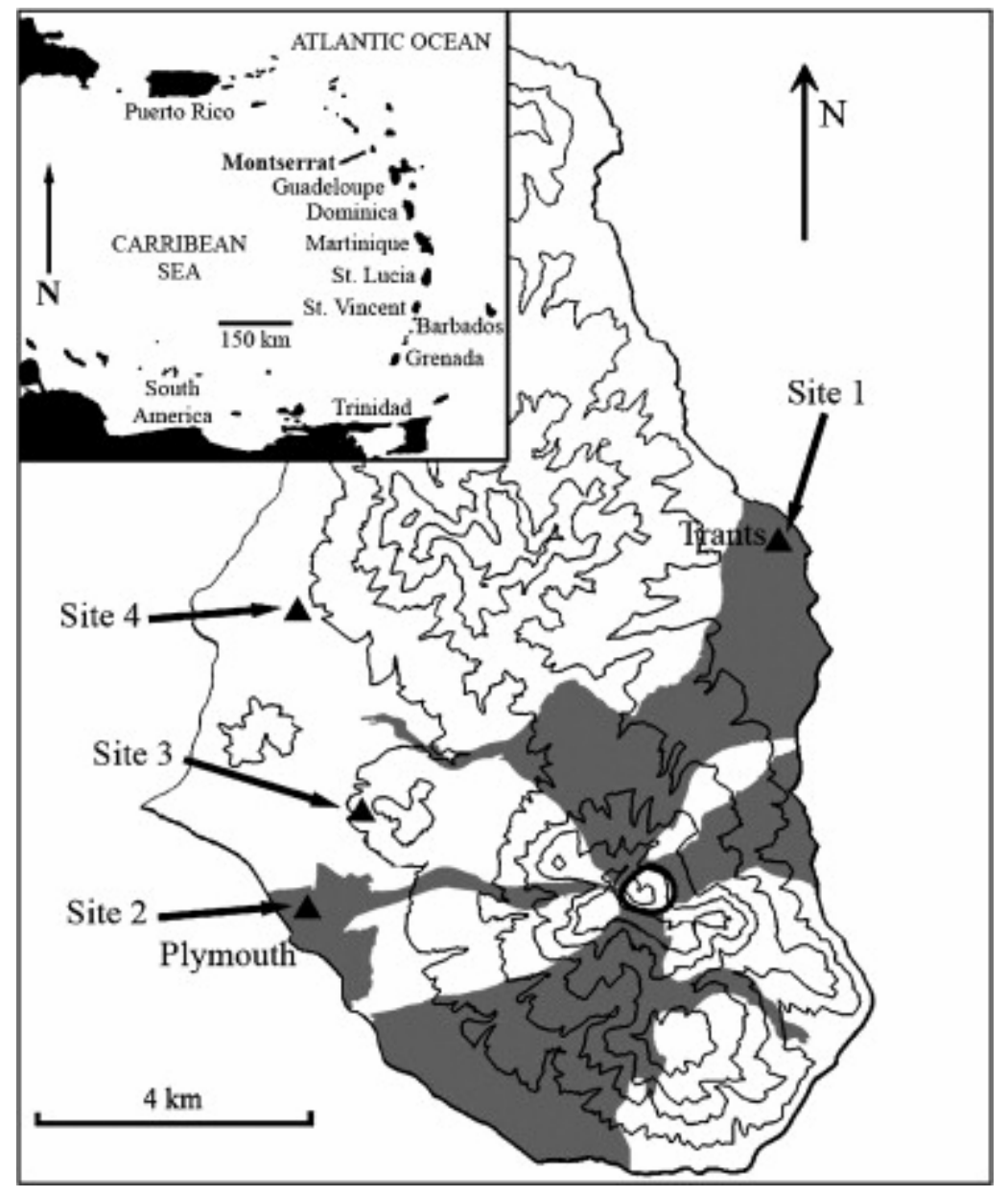

Fig. 1. Map of Montserrat showing Soufrière Hills Volcano and sampling locations. Grey: pyroclastic flow deposits of the 1997 Vulcanian explosions. 

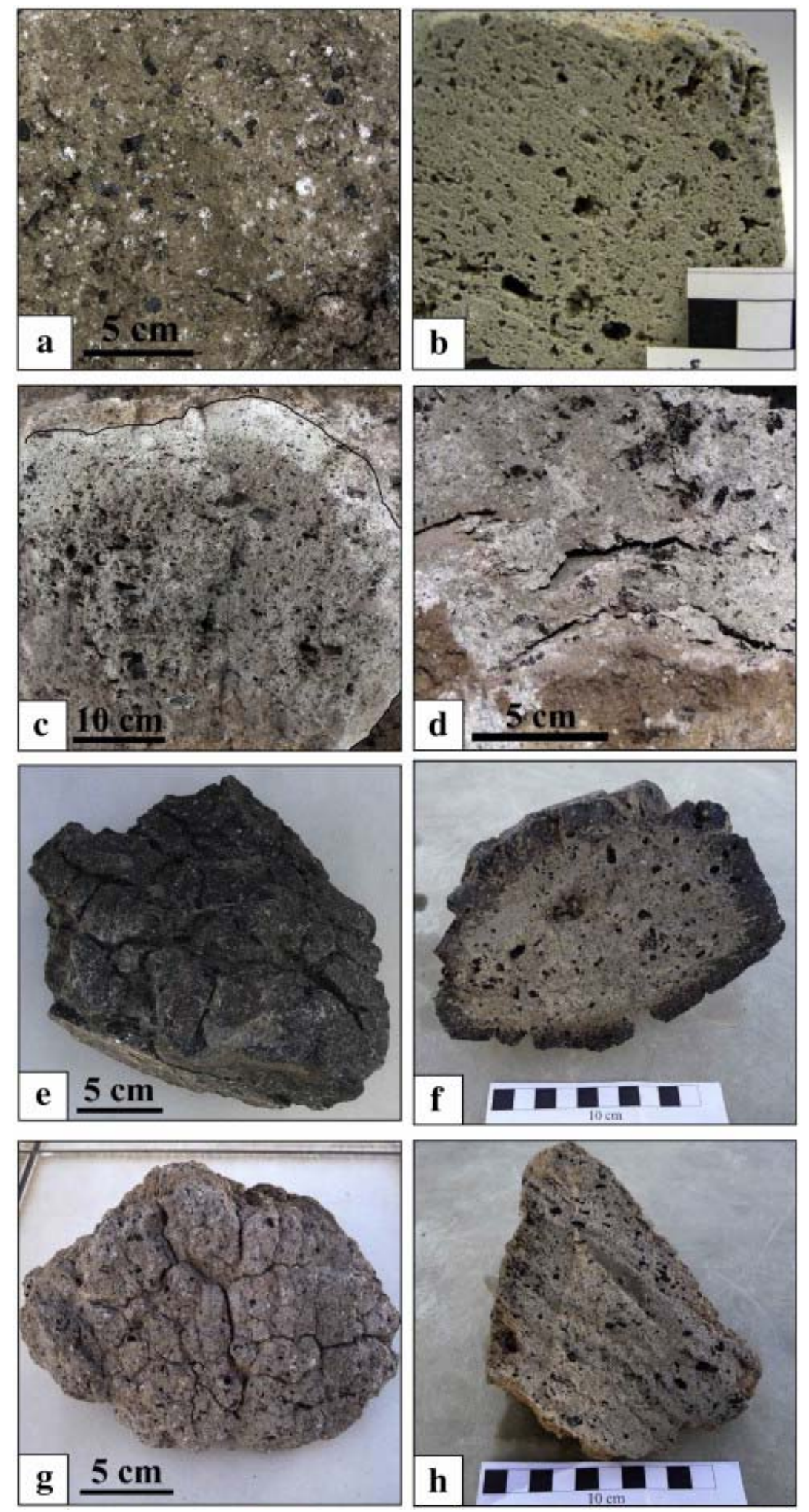

Fig. 2. Pumices and breadcrust bombs from the explosions. a) Dark brown pumice with $60 \%$ vesicularity, b) Pale pumice with $76 \%$ vesicularity, c) Large grey pumice exhibiting a radial gradient in vesicularity, line marks the outer surface of the clast, d) Curviplanar tears and cracks subparallel to clast margins in a dense pumice, e-f) Exterior and cross section of a coarsely breadcrust-bomb, g-h) Exterior and cross section of a finely breadcrusted bomb. 


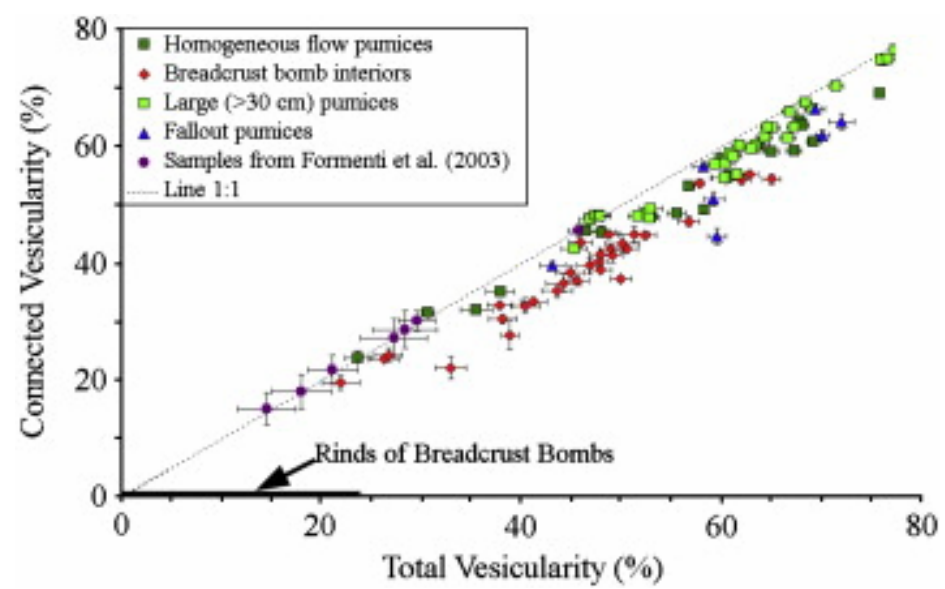

Fig. 3. Plot of connected versus total vesicularity for all the samples of this study. Lava samples from dome collapses at Soufrière Hills Volcano are also shown (Formenti and Druitt, 2003). As connected vesicularities could not be determined for breadcrust bombs rinds, we just show the range of bulk vesicularities obtained (thick black line).

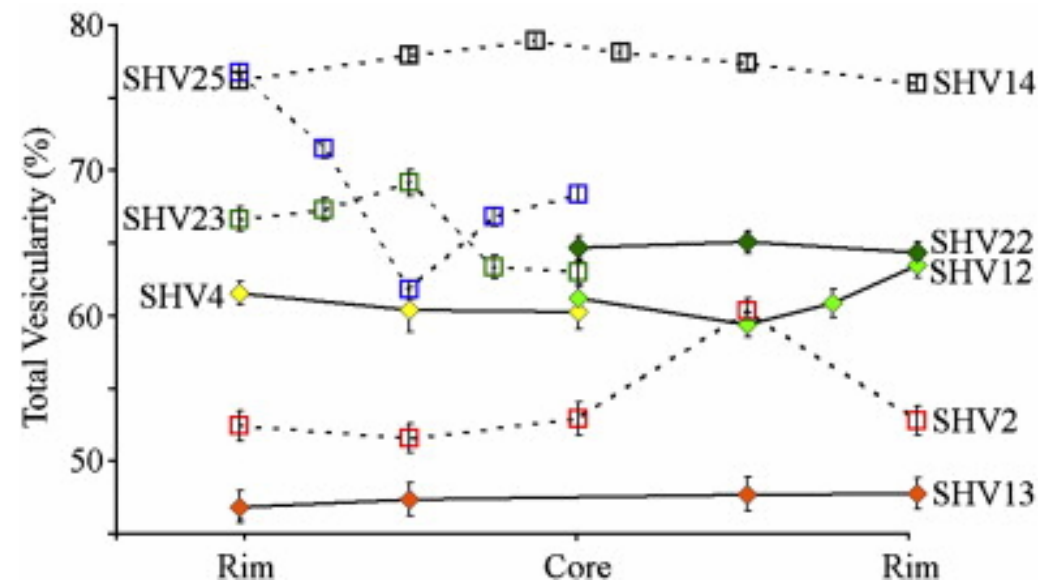

Fig. 4. Vesicularity as a function of relative position inside large pumices $(>30 \mathrm{~cm})$. Filled diamonds with solid lines are those pumices that were judged in the field to be texturally homogeneous; squares with dashed lines are those that had larger vesicles in the interior than in the rind.

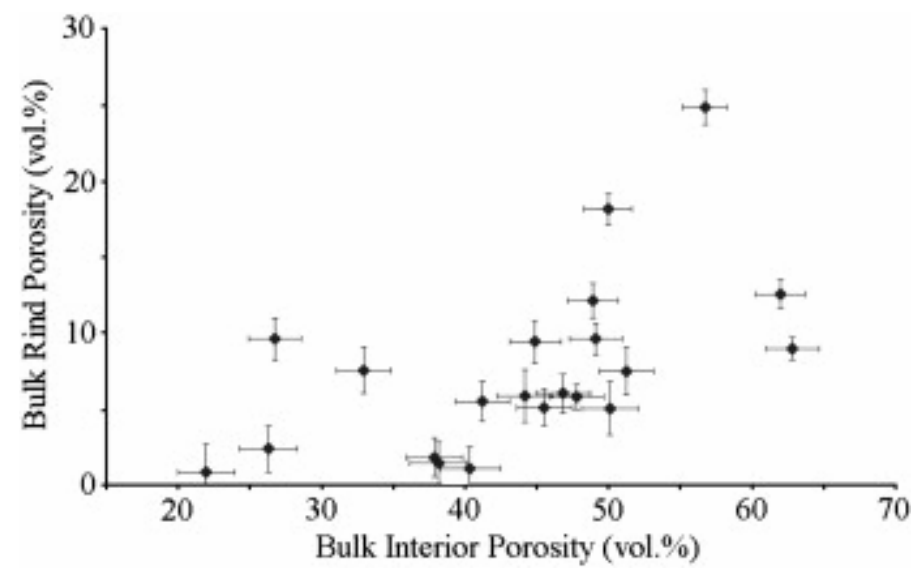

Fig. 5. Relationships between rind and interior vesicularities of breadcrust bombs, including both coarsely and finely breadcrusted types. 

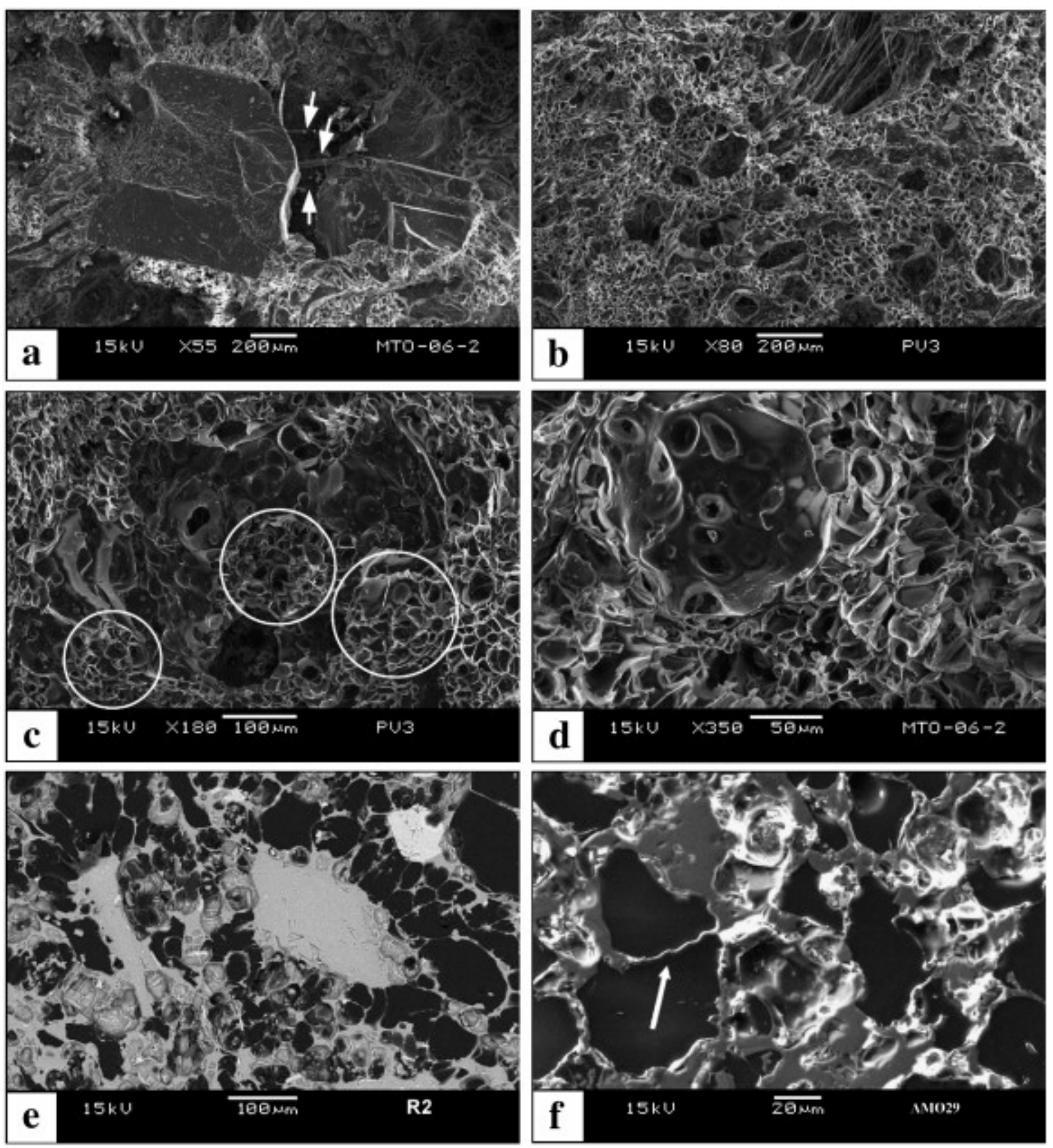

Fig. 6. SEM images of broken surfaces (a-d) and thin sections (e-f) of pumices. a) Angular void in a fractured amphibole phenocryst, the fragments being connected by thin glass fibres (white arrows), b) Visual evidence for three different size populations (large, intermediate and small) of vesicles in pumices, c) Cauliformshaped clusters of small vesicles protruding into intermediate ones, d) Evidence for coalescence of small vesicles to form intermediate-sized ones, e) Microphenocryst of plagioclase surrounded by radiating, elongated vesicles, f) Wrinkling of vesicle wall indicative of the onset of rupture (white arrow). 


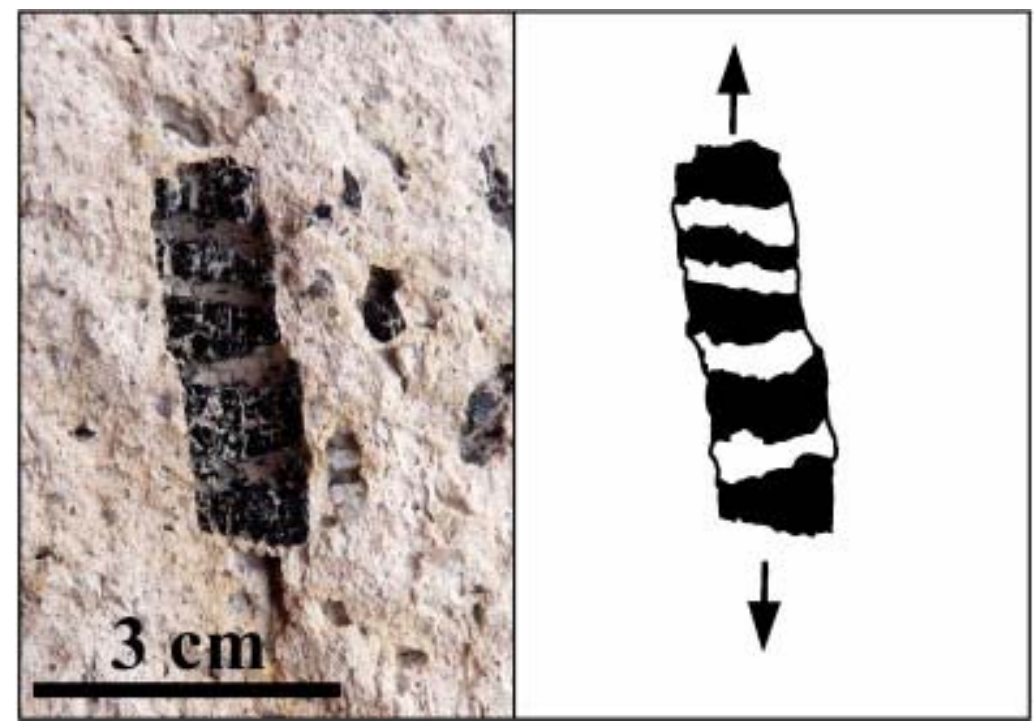

Fig. 7. Uniaxially boudinaged amphibole phenocryst in pumice indicative of significant syn-explosive vesiculation prior to magma fragmentation.

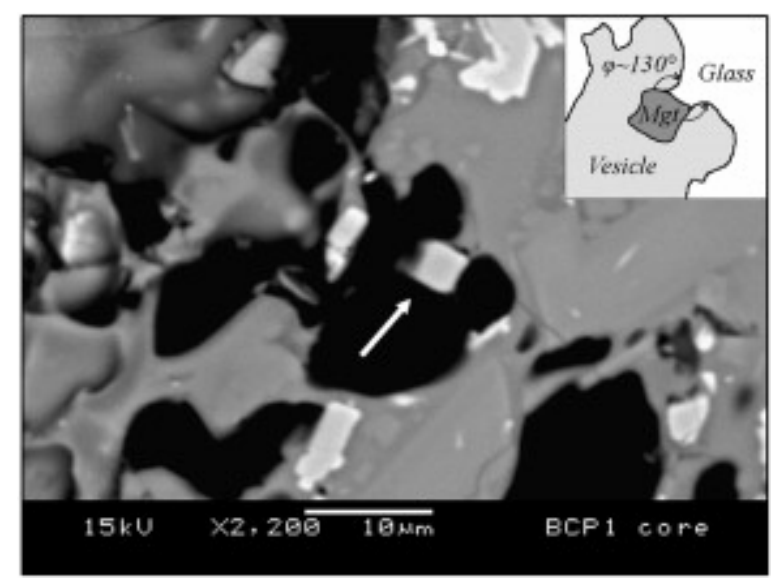

Fig. 8. Textural evidence for heterogeneous nucleation on titanomagnetite. The crystal appears to lack a glass rind, indicating that the gas wetted the solid. This is not the case for amphibole (Fig. 6a) or plagioclase (Fig. 6e), which always have thin glass films separating crystal from vesicle. The wetting angle of this magnetite crystal is $130^{\circ}$, consistent with the high wetting angle $\left(158.5^{\circ}\right)$ proposed by Hurwitz and Navon (1994) for magnetite. 

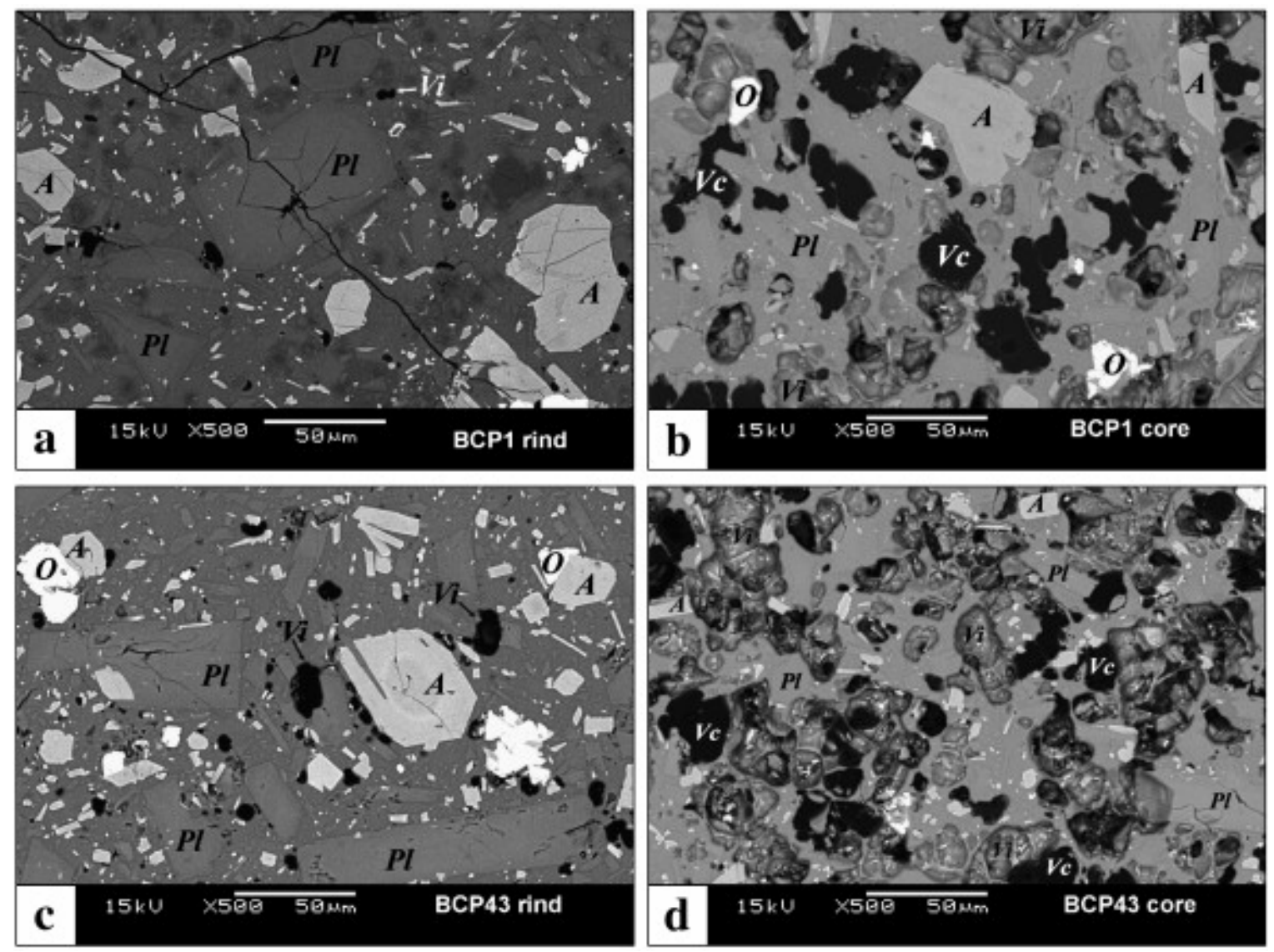

Fig. 9.

Backscattered SEM images of breadcrust bombs. All the images are at the same scale. Labels are: $(A)$ amphibole, $(P l)$ plagioclase, $(O)$ oxide, $(V c)$ connected vesicle, $(V i)$ isolated vesicle. a) Coarsely breadcrusted bomb rind containing rare small isolated vesicles. Note that the bomb rinds are typically very heterogeneous, and vesicles are not present everywhere. The occurrence of areas of rind free of vesicles shows that the coarsely breadcrusted bombs inflated from essentially non-vesicular magma. b) Vesicular interior of coarsely breadcrusted bomb core containing both isolated (non-impregnated: grey) and connected (impregnated: black) vesicles, c) Finely breadcrusted bomb rind with patchily distributed small vesicles; note the higher vesicle numbers than in the rind of the coarsely breadcrusted bomb (a). d) Finely breadcrusted bomb core containing the same two types of vesicles as the coarsely breadcrusted bomb (b), but in greater abundance. 

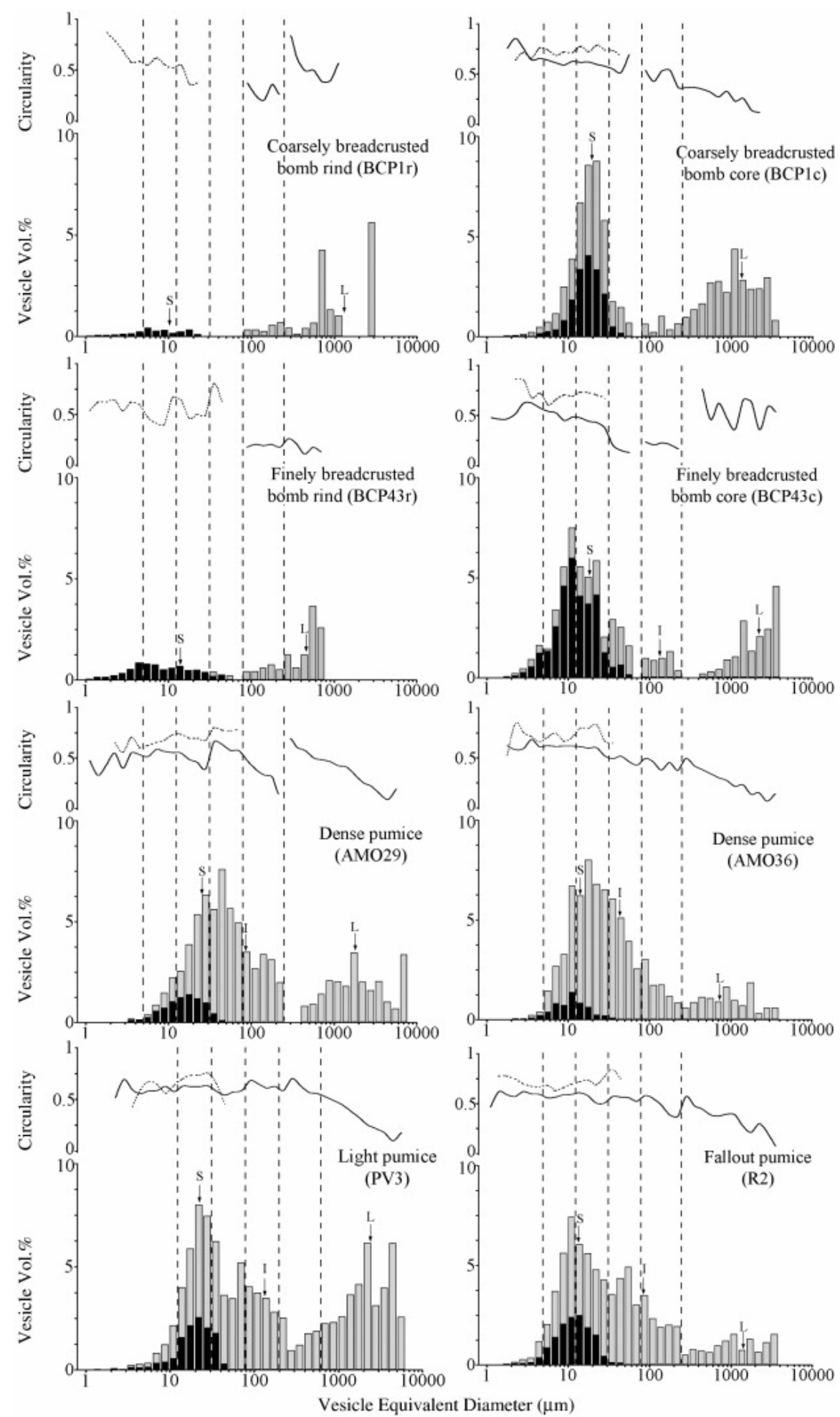

Fig. 10. Glass-referenced (i.e., crystal-free) vesicle-volume distributions (lower part of each graph) and circularities (upper part of each graph) as functions of size. Connected vesicles are shown in grey and isolated ones in black. The vertical dashed lines are the magnification limits of the analysed images. Circularities of isolated vesicles marked as dashed lines and connected vesicles as solid lines. The black arrows on each graph show the mode of each of the small (S), intermediate (I) and large (L) vesicle populations (Table 1) 


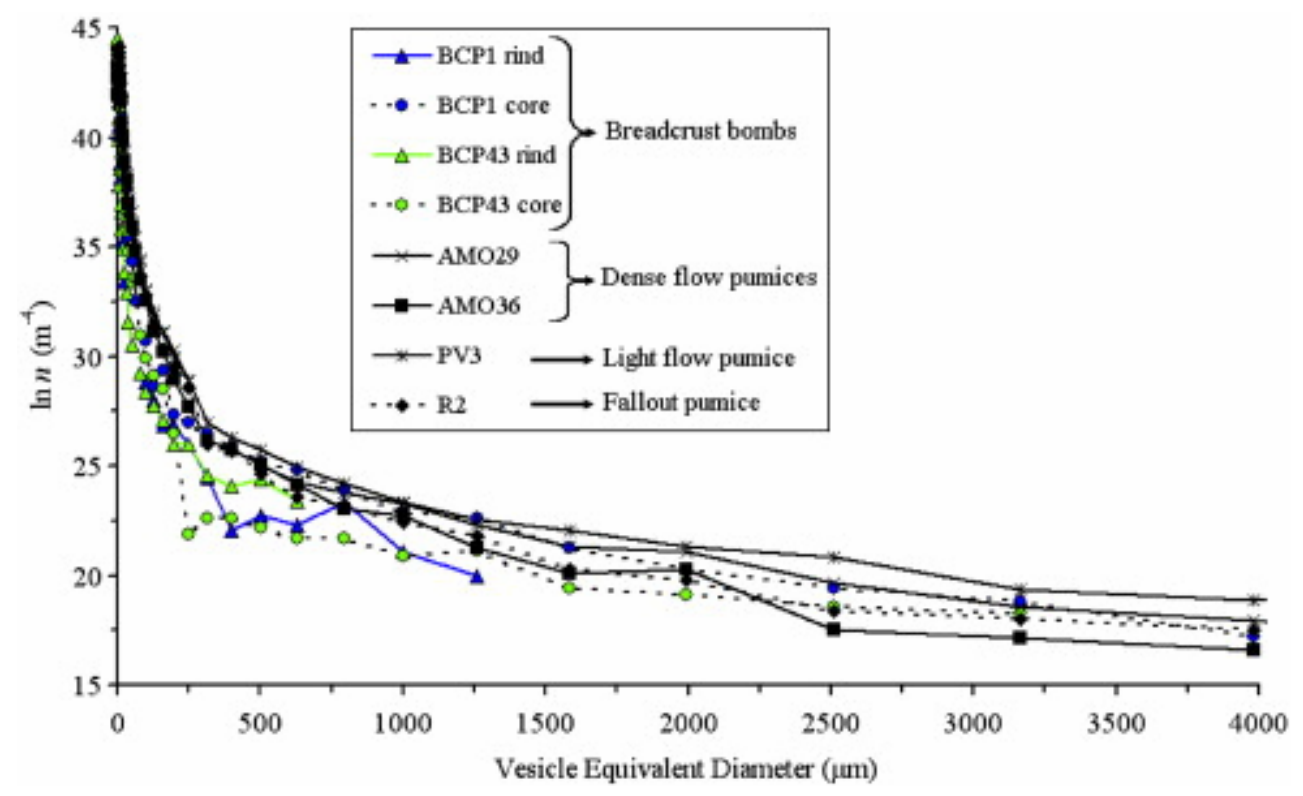

Fig. 11. Vesicle size distributions for the eight pyroclasts analysed in detail.

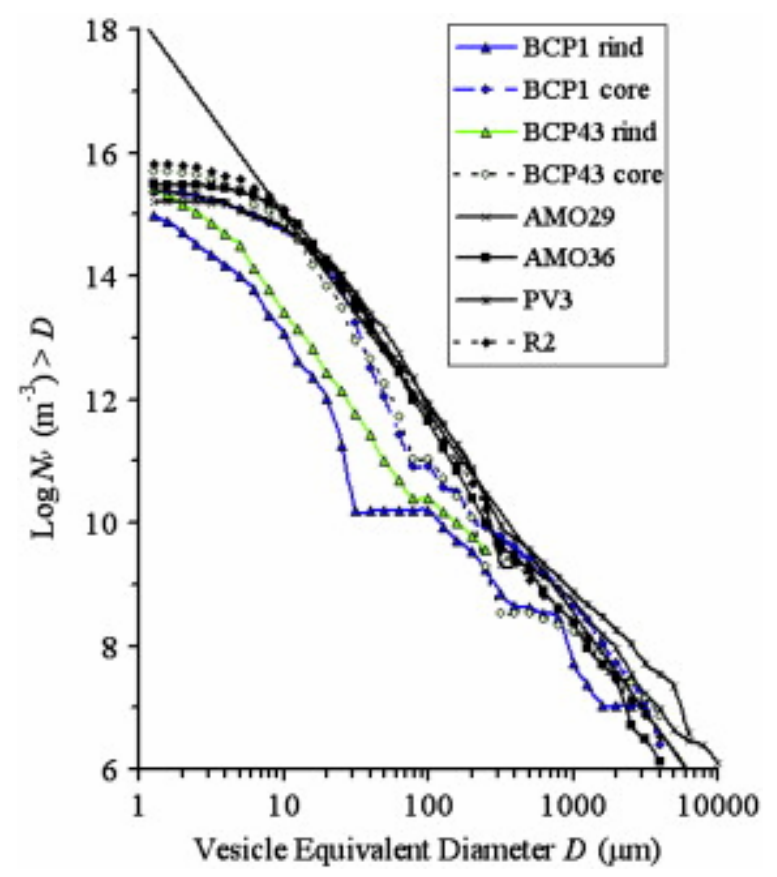

Fig. 12. Cumulative number densities $\left(N_{v}>D\right)$ for the eight pyroclasts analysed in detail. 

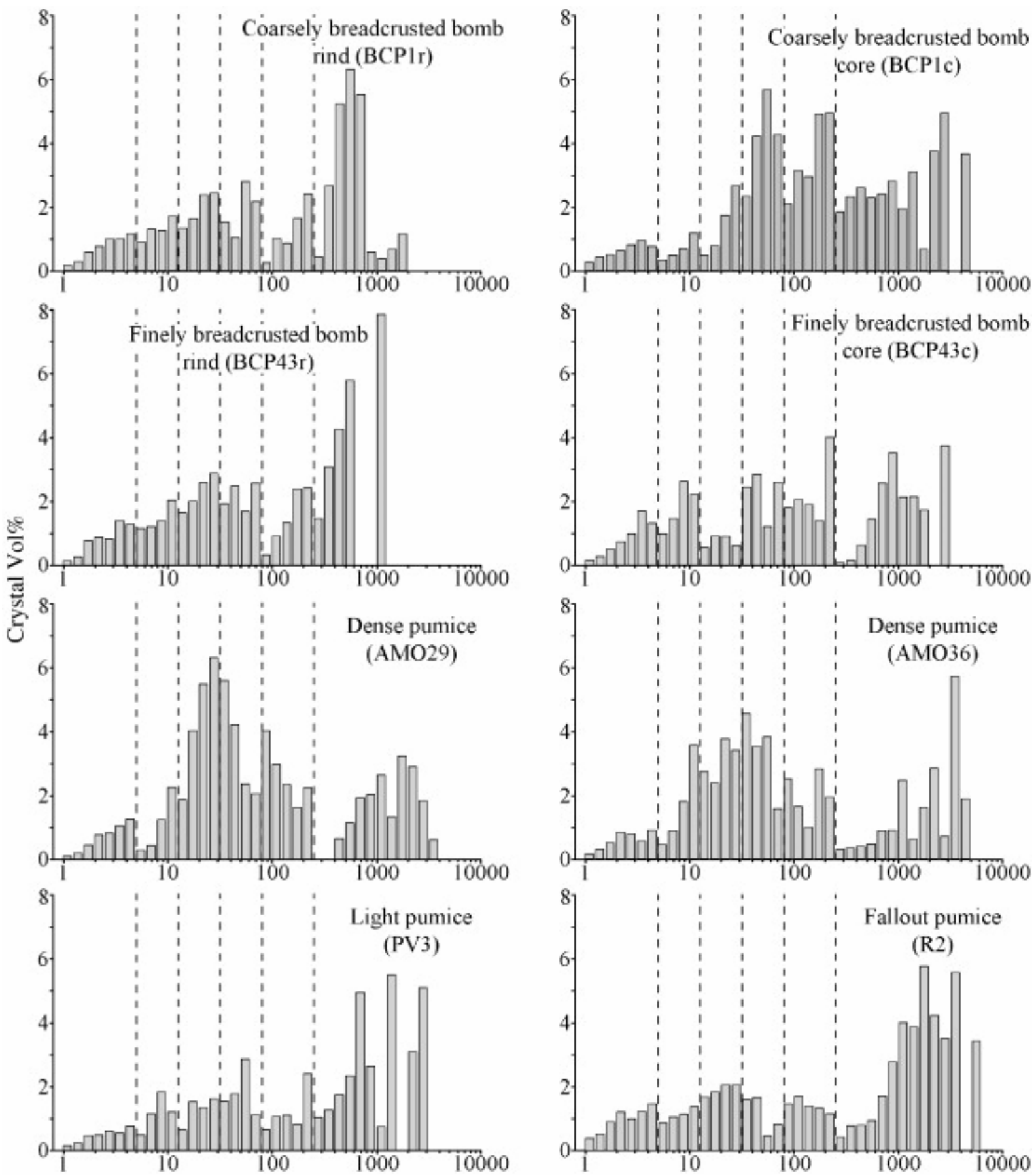

Crystal Equivalent Diameter $(\mu \mathrm{m})$

Fig. 13. Glass-referenced crystal volume distributions. 


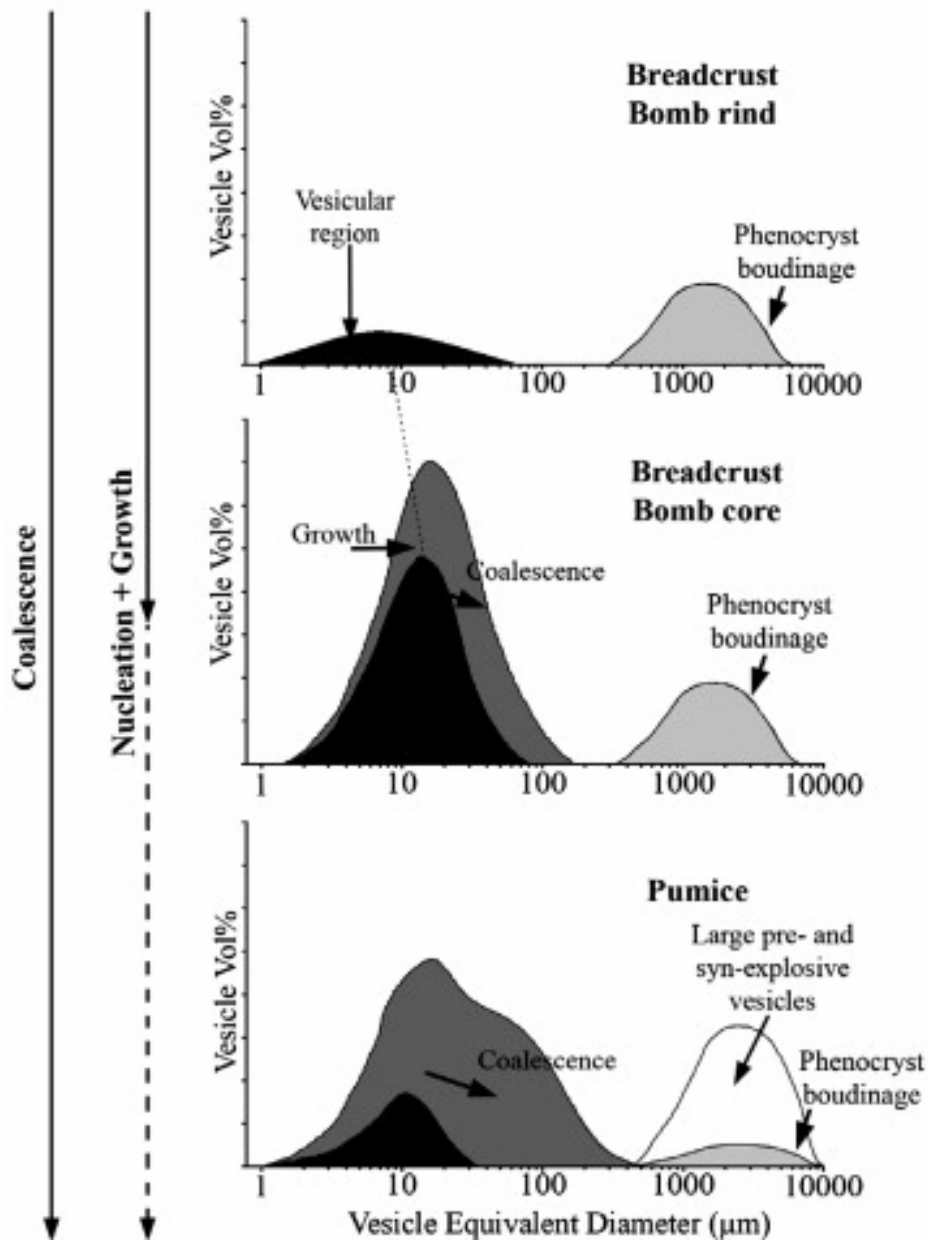

Fig. 14. Schematic illustration showing the development of vesicle volume distributions of breadcrust-bomb rinds, breadcrust-bomb cores and pumices. Isolated syn-explosive vesicles in black and connected syn-explosive vesicles in dark grey. Those in light grey are angular voids formed by syn-explosive fracturing of amphibole phenocrysts. Large, pre-explosive vesicles in pumices are shown in white. Coalescence to form the intermediate-sized vesicles (dark grey) is most advanced in the pumices 


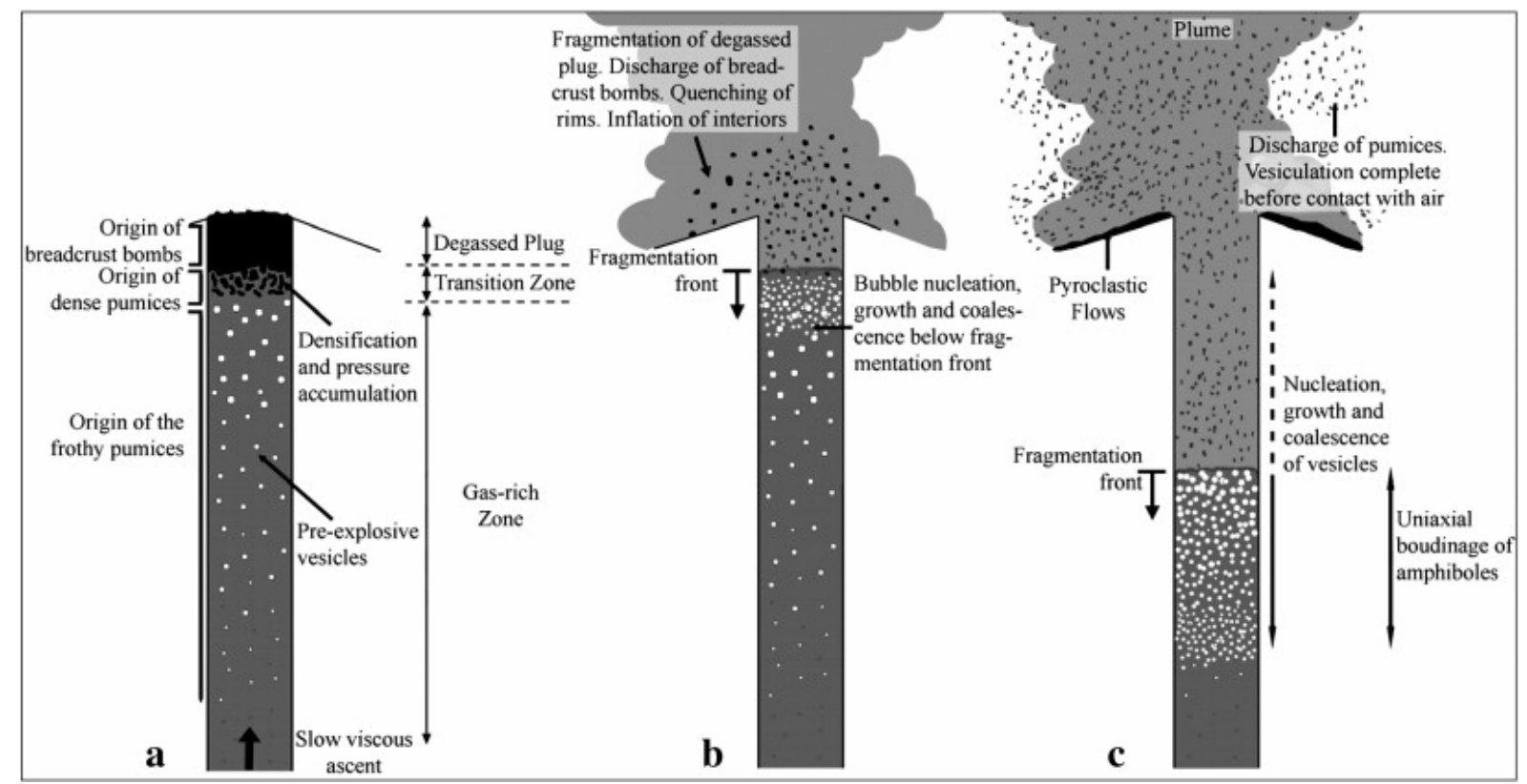

Fig. 15. Summary of vesiculation processes during an average 1997 Vulcanian explosion. 